NBER WORKING PAPER SERIES

\title{
MEDICATION OF POSTPARTUM DEPRESSION AND MATERNAL OUTCOMES: EVIDENCE FROM GEOGRAPHIC VARIATION IN DUTCH PRESCRIBING
}

\author{
Janet Currie \\ Esmée Zwiers \\ Working Paper 29439 \\ http://www.nber.org/papers/w29439 \\ NATIONAL BUREAU OF ECONOMIC RESEARCH \\ 1050 Massachusetts Avenue \\ Cambridge, MA 02138 \\ October 2021
}

The authors wish to thank the NOMIS Foundation for financial support. Kelly Noonan, Maria Stanfors, and seminar participants at Princeton University, the 2021 European Economics Association meetings, and the IZA Workshop: Economics of Time Use and Mental Health provided valuable comments. We also thank Statistics Netherlands (Centraal Bureau voor de Statistiek) and especially contact Fatima El Messlaki for their help accessing the data. The views expressed herein are those of the authors and do not necessarily reflect the views of the National Bureau of Economic Research.

NBER working papers are circulated for discussion and comment purposes. They have not been peer-reviewed or been subject to the review by the NBER Board of Directors that accompanies official NBER publications.

(C) 2021 by Janet Currie and Esmée Zwiers. All rights reserved. Short sections of text, not to exceed two paragraphs, may be quoted without explicit permission provided that full credit, including $(\odot$ notice, is given to the source. 
Medication of Postpartum Depression and Maternal Outcomes: Evidence from Geographic Variation in Dutch Prescribing

Janet Currie and Esmée Zwiers

NBER Working Paper No. 29439

October 2021

JEL No. I1,J19

\begin{abstract}
Using data on over 420,000 first time Dutch mothers, we examine the effects of postpartum antidepressant use on a wide range of maternal outcomes including further treatment for severe mental illness, labor market outcomes, and family formation. We exploit rules which state that Dutch general practitioners (GPs) must be available to make house calls to their patients. In practice many therefore use postal code boundaries to limit their practices. We instrument a postpartum woman's receipt of antidepressants with the propensity to prescribe antidepressants to women aged 46 to 65 among GPs in her postal code. Ordinary Least Squares estimates suggest highly negative effects of postpartum treatment with antidepressants, but this is mainly due to selection into treatment. Instrumental variable estimates suggest that the marginal patient treated with postpartum antidepressants is much more likely to continue taking antidepressants longterm, with little evidence of effects on other outcomes.
\end{abstract}

Janet Currie

Department of Economics

Center for Health and Wellbeing

185A Julis Romo Rabinowitz Building

Princeton University

Princeton, NJ 08544

and NBER

jcurrie@princeton.edu

Esmée Zwiers

Center for Health and Wellbeing

219 Julis Romo Rabinowitz Building

Princeton University

Princeton, NJ 08544

ezwiers@princeton.edu 


\section{Introduction}

Postpartum depression (PPD) is defined as a major depression that begins within four weeks of giving birth (Miller, 2002). It is estimated to affect one in nine postpartum women (Office on Women's Health, 2019). Past research on depression suggests that PPD could have negative impacts on important economic outcomes such as employment and earnings. For example, the Centers for Disease Control reports that in the U.S. depression causes 200 million lost workdays each year (Centers for Disease Control and Prevention, 2016). If PPD affects the stability of domestic partnerships then that could also have an effect on the longer-term economic wellbeing of women and their children given that single mothers are more likely to be poor. In the U.S. $80 \%$ of depressed people report some degree of functional impairment with $27 \%$ reporting serious impairment of their work or home life (Pratt and Brody, 2008).

Because of its association with negative outcomes including suicide and self-harm, improving treatment for postpartum depression is viewed as an urgent priority. Treatment with antidepressant drugs has been described as "the mainstay" of treatment for postpartum depression (Miller, 2002). However, a Cochrane review (Molyneaux et al., 2014) found that studies of postpartum antidepressant use suffered from small samples, high attrition, and unrepresentative participation (caused for example by the exclusion of the most severely depressed women from experimental studies). The review also flagged short follow up periods as a problem since little information is available about medium and longer-term outcomes. Hence, their review called for further research into the efficacy of antidepressant treatment.

This study uses Dutch administrative data covering a sample of over 420,000 first births between 2008 and 2016 to estimate the effects of postpartum antidepressant use on outcomes in the three years following childbirth. By using comprehensive administrative data, we solve many 
of the problems of the previous literature. We have large samples, a three-year follow-up, virtually no attrition, and a sample consisting of all first births rather than a selected sample of new mothers. We are also able to focus on a range of outcomes that are important to a woman's economic wellbeing, including employment, earnings, the stability of domestic partnerships, and the probability of suffering a more severe mental illness in future.

Because antidepressant use is not random, we instrument a woman's receipt of antidepressants using the propensity of local doctors (defined as those in the new mother's fourdigit postal code) to prescribe antidepressants to 46 to 65 -year-old women. This instrument takes advantage of several institutional features of the Dutch health care system: First, in the Netherlands, general practitioners (GPs) are the gatekeepers to mental health care and prescribe most antidepressants; second, GPs must be available to make house calls to their patients. GPs can decline to serve patients living more than 15 minutes away and commonly limit their practices to patients in their own postal codes. We show that conditional on other features of the postal code and on area fixed effects, our instrument is not related with individual-level characteristics of the mothers. And because the instrument is constructed using 46 to 65 -year-old women, the attitudes of new mothers themselves towards antidepressant use should not have a direct effect on this measure of prescribing propensity.

Consistent with the prior literature, Ordinary Least Squares estimates of the effects of postpartum antidepressant treatment suggest that it has pervasive negative effects on all of the outcomes considered. The marginal woman prescribed antidepressants postpartum is more likely to be taking antidepressants up to three years later; more likely to be being treated by a specialist for a more severe psychiatric disorder; less likely to have any positive earnings; less likely to live with the child's father, and less likely to have another baby within three years. 
In contrast, our instrumental variable estimates suggest that these negative estimated OLS effects are largely driven by negative selection into antidepressant use. Controlling for this selection, we still find that those women who were initially prescribed antidepressants because they live in a high-prescribing area are more likely to be using them long-term. Moreover, women in the top quartile of the pre-pregnancy income distribution are more affected by the prescribing propensity instrument, suggesting that these women are more likely to be the "marginal" antidepressant patients.

However, we find few statistically significant effects on the other outcomes examined. This result raises the question of whether antidepressants are being overprescribed since long-term use of antidepressants has side effects including significant weight gain, sexual problems, emotional numbness, a higher risk of new cardiovascular events, and even a higher risk of death (Bet et al., 2013; Maslej et al., 2017). Hence, long-term antidepressant use is justified only if it actually improves outcomes. Our results suggest that more attention should be paid to whether the marginal patient treated for postpartum depression benefits from antidepressant use.

The rest of the paper is laid out as follows. Section 2 provides additional background information. Section 3 gives an overview of our empirical approach. Section 4 describes the data, and Section 5 shows the results. A discussion and conclusion follow.

\section{Background}

This section provides a very brief overview of some of the research on postpartum depression, as well as the unique institutional features of the Netherlands which enable our study. 


\subsection{Prior literature about the effects of PPD}

Many studies have argued that PPD interferes with a mother's ability to bond with her baby, with negative effects on early child development (Slomian et al., 2019; Moore et al., 2018; Netsi et al., 2018). Some studies also suggest that PPD is associated with increased stress, anxiety, and depression among partners (Moore et al., 2018) and more conflict in the home (Burke, 2003). Other studies emphasize links with suicidal ideation and self-harm (Moses-Kolko et al., 2016;

Bodnar-Deren et al., 2016). PPD has also been linked to inadequate housing, food insecurity and economic distress among mothers and children, though it is not entirely clear whether it is a cause or an effect of these outcomes (Curtis et al., 2014; Garg et al., 2014; Corman et al., 2016; Noonan et al., 2016; Williams and Cheadle, 2015).

However, very few studies have examined the longer-term impacts of postpartum depression on mothers themselves. Vliegen et al. (2014) review longitudinal studies of the course of the disease and find that while most women eventually recover from PPD, it is a significant risk factor for subsequent mental illness. Given that depression accounts for large numbers of working days lost in industrial economies, and that chronic depression can lead to withdrawal from the labor market, it is possible that PPD has long-term negative labor market outcomes. In one of the only studies to examine the effects of PPD on the return to work, Dagher, Hofferth, and Lee (2014) find that PPD had no statistically significant effect, but this may be an artefact of a relatively small sample size.

Postpartum depression could also affect women’s longer-term economic status through effects on family formation. Given that single mothers are much more likely to suffer from low household income than partnered mothers, PPD could undermine financial security by making it less likely that a new mother would stay partnered. 
This summary highlights the lack of attention to the medium and longer-term effects of PPD and treatment for PPD on the women themselves. This paper aims to begin to fill this gap in the literature.

\subsection{Institutional Features of Dutch Health Insurance and Maternity Care}

In the Netherlands, the 2006 Health Insurance Act created a unified system in which all residents are required to purchase health insurance with a predefined set of 'basic' benefits from private insurers. Subsidies are available for low income residents. Insurance companies can compete by offering these basic benefits at different prices (i.e. there is managed competition). The set of 'basic' benefits is updated by the Ministry of Health each year. It covers medical care by general practitioners, midwives and specialists, as well as dental care, and pharmaceuticals. ${ }^{1}$ Hence, anyone who needs treatment for PPD can access it for free.

The GP serves as a gatekeeper for specialist care, including mental health care (Van Dijk, et al., 2013). GPs treat patients with mild mental health problems themselves and can refer more serious cases to specialists. ${ }^{2}$ One recent report found that out of 879 individuals who visited a GP for depressive symptoms, $78 \%$ of individuals received a referral to another health professional, such as a therapist, and $41 \%$ were prescribed medication (MIND, 2019). The majority of antidepressant prescribing is done by GPs: In 2004, GPs were responsible for $79.6 \%$ of the antidepressants prescribed in the Netherlands (SFK, 2005), while in 2019, they accounted for 65\% of new prescriptions for antidepressants (SFK, 2020).

\footnotetext{
${ }^{1}$ Out of pocket costs are low. A mandatory deductible was introduced in 2008 that increased from 150 euros in 2008 to 385 euros in 2020. However, some services, like GP care, are excluded from this deductible.

${ }^{2}$ A reform was introduced in 2014 that made it harder for patients to get a referral from a GP for specialized care. As a result even more patients with mental health problems were treated by their GP.
} 
As in the United States, any doctor can prescribe antidepressants and most antidepressants are covered by basic insurance. ${ }^{3}$ Over our sample period (2006 to 2018) 5.7\% of the Dutch population used antidepressants. The rate was higher among prime-aged women (15 to 45 ) at 6.0\% and it was even higher for women 46 to 65 at $11.2 \% .{ }^{4}$ These numbers are lower than for the US where $13.2 \%$ of all adults, $17.7 \%$ of women, and $24.3 \%$ of women over 60 used antidepressants over the 2015 to 2018 time period (Brody \& Gu, 2020).

In the Netherlands there are guidelines that cover the treatment of depression during and after pregnancy. This study focuses on the treatment of postpartum depression, defined as depression that occurs within the ten months following the pregnancy. The Dutch guidelines acknowledge that antidepressant use during pregnancy involves possible tradeoffs between benefits to the mother and possible harms to both the mother and the fetus, but conclude that antidepressants, and in particular SSRIs, should not necessarily be discouraged during pregnancy (NVOG, 2012; Molenaar, 2018). ${ }^{5}$ As we will show however, many Dutch women avoid taking antidepressants during pregnancy and even discontinue them during pregnancy perhaps for fear of potential harm to the fetus.

With regards to postpartum depression, the guidelines of the Dutch Association of General Practitioners (NHG, 2019) state that it is important to diagnose and treat it. The guidelines state that while psychotherapy is an effective treatment for postpartum depression, doctors can opt to prescribe antidepressants as well. The guidelines do not discourage the prescription of antidepressants for women who are breastfeeding, nor do they suggest that women who are on

\footnotetext{
${ }^{3}$ In some cases, only the generic version of the antidepressant is covered by basic insurance.

${ }^{4}$ Authors' calculations based on microdata from Statistics Netherlands. Usage of antidepressants corresponds to any prescription for antidepressants (prescription in ATC-4 category N06A) in a year, and we average the usage by group over the years 2006 to 2018 to get to these numbers.

${ }^{5}$ For example, O’Connor et al. (2016) provide a review of the literature that reports higher rates of miscarriage, seizures, and pre-eclampsia in women taking antidepressants.
} 
antidepressants should not breastfeed. ${ }^{6}$ It is important to note that, even though midwives and pediatricians can help to identify the first signs of potential postpartum depression in women, new mothers have to go to their GP to receive treatment for this condition.

Dutch women are entitled to six weeks of pregnancy leave and at least ten weeks of maternity leave. Pregnancy leave lasts until the day of giving birth and can start six to four weeks before the woman's due date. After giving birth, women are entitled to at least ten weeks of maternity leave (more if the baby was early so that they did not use all of their pregnancy leave). Maternity benefits are equal to $100 \%$ of daily wages. Employers continue to pay the woman's salary during her pregnancy and maternity leave and then request reimbursement of the benefits from the social insurance administration. ${ }^{7}$ The main implication of these policies for our analysis is that if a woman is willing and able to return to work after giving birth, we should see her return within the year.

In summary then, there are few barriers to a woman receiving an antidepressant for postpartum depression if her doctor thinks that it is warranted. Guidelines would support such prescribing, and public insurance would pay for it. And most women who return to work, should be observed to do so after a relatively short period of maternity leave.

\section{Empirical Strategy}

Our goal is to assess the effects of taking antidepressant drugs for postpartum depression sometime in the 10 months after giving birth on a woman's future well-being measured using the broad range

\footnotetext{
${ }^{6}$ There is little evidence on the effects on antidepressants during lactation on infants, and there is no evidence for severe negative consequences. The guidelines do recommend the usage of particular antidepressants during lactation (NVOG, 2012; NHG, 2019).

${ }^{7}$ If a woman is not able to return to work after maternity leave ends because of an illness due to her pregnancy, she is entitled to receive sickness benefits equal to $100 \%$ of daily wages for a maximum of 104 weeks. If an individual is still sick after 2 years they will transition into the fund for long-term illness (WIA).
} 
of outcomes available in Dutch administrative data. The main difficulty is that there are likely to be unobserved (to the researcher) attributes of women which are correlated both with their propensity to be prescribed antidepressants and with their future outcomes.

In order to try to identify a causal effect of antidepressant use, we focus on a group of women who are delivering for the first time and who were not taking antidepressants in the 10 to 24 months prior to the delivery. Women who were taking antidepressants prior to the pregnancy may be continuously depressed rather than suffering from postpartum depression. Women delivering for the first time have - by construction - never suffered from postpartum depression before. We focus on this group because previous postpartum depression is a risk factor for experiencing another episode of postpartum depression and might influence subsequent outcomes. ${ }^{8}$

In this sample of first-time mothers who were not being medicated for depression prior to pregnancy, it is still possible that unobserved attributes correlate both with the propensity to use antidepressants after the birth and with future outcomes. Hence, we instrument the woman's own postpartum antidepressant use with a 4-digit postal code level average of local doctors' propensities to provide new prescriptions of antidepressants to women aged 46 to 65 in the year before the birth. This measure is described in more detail below.

Measures of a doctor's propensity to prescribe have been widely used as instruments for patients' probabilities of receiving medications (c.f. Chorniy and Kitashima, 2016; Dalsgaard, Nielsen, and Simonsen, 2014). However, these studies still raise the question of how a patient ended up being matched with a particular provider. In order to deal with this difficulty some

\footnotetext{
${ }^{8}$ Moreover, Figure A1 shows that a woman's propensity to take antidepressants in the months surrounding childbirth is higher for higher-parity births in the raw data (see panel a). This pattern remains even after controlling for maternal age at birth (see panel b).
} 
researchers have turned to area-level measures of the propensity to prescribe. The logic behind using area-level measures is that in areas with high levels of prescribing, individuals are more likely to end up seeing a high prescribing provider (Currie and MacLeod, 2017, 2020; Cuddy and Currie, 2020). This work builds on the large literature demonstrating the importance of geographical variations in treatment patterns (e.g. Finkelstein et al., 2015; Fischer et al., 2003a,b; Cutler et al., 2019). A limitation of much of this literature is that in most jurisdictions, it is possible that patients could travel to see a provider who better matched their treatment preferences.

We also make use of an area-level measure of the propensity to prescribe. However, in our case patients are unlikely to travel to find a provider because of an institutional feature of the Dutch health care system: In the Netherlands, GPs are required to be able to make house calls and can decline to take patients who live more than fifteen minutes from their office location (Ministerie voor Volksgezondheid, Welzijn en Sport, 2005). Hence GP practices often work with postal code boundaries in order to determine which patients are accepted as new patients. If for example, there was one GP practice in the neighborhood, then the patient would go to that practice and we would know the provider's propensity to prescribe with certainty. With two or three GP practices in the neighborhood, patients can only go to one of a small number of practices, so the average propensity to prescribe is still be a strong predictor of their own receipt of a prescription.

We focus on new prescriptions of antidepressants to women 46 to 65 in the year prior to the birth an effort to capture the local providers' general attitudes towards the prescribing of antidepressants to women. ${ }^{9}$ We show below that areas where doctors write more new prescriptions for older women are areas in which new mothers are also more likely to receive prescriptions. Given that the instrument is a strong predictor of a woman receiving a postpartum prescription for

\footnotetext{
${ }^{9}$ Note that our data does not allow us to see who prescribed the antidepressants, but we know that the GPs are the largest prescriber of antidepressants in the Netherlands
} 
antidepressants, the additional condition necessary for it to be a valid instrument is that the fraction of 46 to 65 year-old women in the neighborhood who are newly prescribed antidepressants has no independent impact on the outcomes of women 15 to 45 years old, once their own postpartum antidepressant use and other control variables are accounted for. While this assumption is inherently untestable, we do show that our instrument passes a "balance" test as described further below.

As control variables we include the following individual-level controls: Maternal and paternal age at birth (in seven groups, $<20,20$ to 25,25 to 30,30 to 35,35 to $40,>40$, and missing for fathers); maternal and paternal migration background (Dutch background or not); an indicator that the birth was a multiple birth; maternal and paternal mean income and maternal and paternal labor force participation in the two years preceding the birth. We also include an indicator for whether the parents are living together in the year before birth.

In addition, we include the following postal code level controls: the percent of inhabitants with a Dutch background, percent one-parent households, percent welfare recipients; percent low income households, and five indicators for the "urbanicity" of the postal code. We also include a control variable for the total population in the child's year of birth, and controls for mean income and mean labor force participation for men and women between the ages of 15 to 45 in the year before childbirth.

Finally, we include "municipality" and year of birth fixed effects. In the Netherlands the concept of a municipality is closer to the U.S. idea of a county than to a city. The entire country is divided into municipalities which generally include a city, village, or town as well as its surrounding area. ${ }^{10}$ Each municipality is further divided into postal codes. One could reasonably

\footnotetext{
${ }^{10}$ The boundaries of municipalities can change over time, generally because smaller municipalities merge into larger units. We take this into account by matching the postal codes to the 2016 municipality boundaries.
} 
think of the municipality as corresponding to the local labor market and transportation network. We divide the four largest cities (Amsterdam, Rotterdam, The Hague and Utrecht) up into districts to account for possible regional differences within cities. Our sample is comprised of 2,001 postal codes that belong to 481 different areas (municipalities plus districts). We cluster standard errors at the area level.

Hence, the first stage equation we estimate is of the form:

$$
A D_{i z j t}=\alpha_{j}+\beta_{1} G P_{-} \text {prop }_{z j t}+\beta_{2} X_{i z j t}+\beta_{3} Z i p_{z j t}+\varphi_{t}+\varepsilon_{i z j t}
$$

where $A D_{i z j t}$ denotes antidepressant use by individual $i$, in postal code $z$, in municipality $j$, in year $t$; GP_prop ${ }_{z j t}$ denotes the propensity of doctors to prescribe antidepressants in the postal code, i.e. new prescriptions to women aged 46 to $65 ; X_{i z j t}$ is a vector of individual-level attributes; $Z i p_{z j t}$ is a vector of postal code level attributes; $\varphi_{t}$ is a vector of year fixed effects for the year of birth of the child, $\alpha_{j}$ is a vector of area fixed effects and $\varepsilon_{i z j t}$ is an error term. Standard errors are clustered at the area level.

Denoting the predicted probability of antidepressant use from the first stage as $\operatorname{Pred} A D_{z j t}$ the second stage takes the form:

$$
Y_{i z j t}=\delta_{j}+\gamma_{1} \operatorname{PredAD}_{z j t}+\gamma_{2} X_{i z j t}+\gamma_{3} Z i p_{z j t}+\theta_{t}+\varepsilon_{i z j t}
$$

where $\mathrm{Y}_{\mathrm{izjt}}$ is one of a number of maternal outcomes as described further below.

As we show below, areas where doctors are more likely to prescribe antidepressants to women 46 to 65 tend to be relatively depressed places, with higher fractions of low-income individuals. Hence, in order to better distinguish between the effects of income and the effects of 
prescription propensities, we also estimate separate models for relatively high-income individuals (top 25\% of the pre-pregnancy family income distribution) and other individuals.

\section{The Data}

We use administrative data from Statistics Netherlands. It covers the universe of individuals born or living in the Netherlands after 1995 and includes data on prescription drug use between 2006 and 2018. ${ }^{11}$ This section offers further information about the construction of the instrument, the sample of births, the linkage of antidepressant prescriptions to births, and the outcomes we examine.

\subsection{Building the instrument}

We use geographic variation in prescribing as an instrument for antidepressant usage in the months after giving birth. We focus on postal codes as the geographic unit of analysis because it is the local area that determines the choice of GP. To construct the instrument, we start by assigning individuals to the 4-digit postal code of residence in each year of the sample. In some cases, an individual may have had more than one address in the course of a calendar year, in which case we use the longest spell as their main address.

We combine the address data with information on all of the prescriptions that an individual received from a pharmacy and which were covered by the basic insurance. This file has information about whether the individual received at least one prescription for antidepressants (ATC-4 code: N06A) in a given calendar year. In order to zero in on postpartum antidepressant

\footnotetext{
11 The administrative data from Statistics Netherlands is available at a remote-access facility after signing a confidentiality agreement.
} 
use we also make use of an additional file compiled for us by Statistics Netherlands that has information about the months when each antidepressant prescription was received.

To reliably construct area level prescribing patterns, we focus on 4-digit postal codes that have inhabitants in every year between 2006 and 2018. We drop 74 postal codes that do not have inhabitants in all years which results in a loss of 0.12 percent of all person-year observations. We also require that the postal code has at least one GP practice in all years. In postal codes without a GP practice people are obviously allowed to see a GP elsewhere and we do not know their GP's location. Data on GP locations comes from Nivel (Netherlands Institute for Health Services Research). Postal codes without GP practices account for 18.76 percent of the person-year observations. There are 2,001 postal codes with a GP practice in all years. These postal codes have a mean population of $7,039\left(10^{\text {th }}\right.$ percentile 1,978 , median $6,612,90^{\text {th }}$ percentile 12,587$)$.

The area-level prescribing measure is constructed by focusing on new antidepressant patients among women 46 to 65 . We focus on new patients as their experience is more likely to reflect actual current prescribing practices in the postal code rather than capturing people who are taking antidepressants that were perhaps initially prescribed elsewhere. New patients are defined as individuals who did not receive a prescription the year before. Given that the data start in 2006, our measure of new patients can be determined for the time period 2007 to $2018 .{ }^{12}$ Using an instrument based on prescribing to the mothers in our sample (women aged 15 to 45) could raise concerns about reverse causality as the mothers themselves could be asking their doctors for antidepressants; this is why we focus on women aged 46 to 65 . The instrument reflects the

\footnotetext{
${ }^{12}$ Note that for the measure of new antidepressant patients we need to observe an individual in all years to be able to reliably determine whether they are a new antidepressant patient. Some individuals move abroad for one or more years which means that they are not be observed every year in our data. In practice, we observe $94.4 \%$ of women between the ages of 46 to 65 in all years from 2006 to 2018. The measure of new antidepressant patients based on all women aged 46 to 65, and women aged 46 to 65 who we observed for all thirteen years are very highly correlated (correlation coefficient of 0.996).
} 
proportion of women aged 46 to 65 in each postal code who are new antidepressant patients. The mean value of the instrument at the municipality-year level is 0.020 (which implies that in the mean municipality-year, 20 out of every 1,000 women are using antidepressants). The $10^{\text {th }}$ percentile 0.011 and the $90^{\text {th }}$ percentile is 0.030 .

Figure 1 shows the variation in the instrument in 2009 and 2016. One can see that there is a great deal of variation within fairly small geographical areas, and even within municipalities (municipal boundaries are indicated in black). Note that by excluding the smallest postal codes, we have greatly reduced the amount of variation that is due to small sample sizes. The figure also shows that prescribing intensity has tended to increase over time.

Table 1 shows the correlation of the instrument (new patients among women aged 46 to 65) with a measure of new antidepressant patients among women aged 15 to 45, and other background characteristics of postal codes. Prescribing of antidepressants to women aged 46 to 65 is positively related to prescribing to women aged 15 to 45 (0.3849). The table also shows that prescribing intensity is higher in postal codes with larger populations, lower shares with a Dutch background, larger shares of low-income households, and with larger shares of welfare recipients. These characteristics of postal codes are all controlled for in our models, as discussed above.

\subsection{The Sample of Births}

To create the sample of mothers we start with the registry of persons (GBAPERSOONTAB) and use the parent-child register (KINDOUDERTAB) to match children to parents. For all births we know parity, whether it is a multiple birth, spacing between siblings, parental age at birth, and parental migration background. The sample is restricted to first births that occurred between January 2008 and before July $2016(\mathrm{~N}=688,343)$ so that we can identify antidepressant use for 
the mother in the 24 months prior to birth and the 30 months after birth for our sample. We drop births to mothers younger than 15 and older than 45 at birth $(\mathrm{N}=846)$.

We assign mothers to 4-digit postal codes based on the first postal code that we observe for them in the 24 months prior to giving birth. We drop 2,478 observations for whom we cannot observe a postal code in the 24 months prior to giving birth. ${ }^{13}$ We then restrict our sample to mothers who were living in postal codes that had inhabitants over the entire 2006 to 2018 time period, and mothers living in postal codes that had at least one GP practice over the 2009 to 2016 time period. We have to drop $17.69 \%$ of births $(121,184)$ and are left with 563,835 births. We restrict our sample to births to mothers who were born in the Netherlands, since we are most likely to observe both prescription drug usage and labor market outcomes over time for this sample. These restrictions leave us with 468,056 observations. We keep one observation per mother for multiple births $(\mathrm{N}=460,138)$. Finally, we drop $2.6 \%$ of mothers who are not observed in the income data in the 2 calendar years before childbirth, the calendar year of childbirth, and the three calendar years after childbirth, as these women may not have lived in the Netherlands in all years. ${ }^{14}$ Our final sample consists of 448,226 births. The prescribing intensity instrument - the proportion of new antidepressant patients among women aged 46 to 65 - is assigned based on the mother's postal code of residence in the year prior to giving birth.

\footnotetext{
${ }^{13}$ The house call rule that we exploit is only applicable to new patients at GP practices. This means that individuals could move and still stay with their previous GP. We try to take this "stickiness" into account by measuring postal code by taking the first postal code that we observe for the woman in the 24 months prior to giving birth. The instrument is measured for this location but the timing is that we assign the value of the instrument in the year prior to the childbirth.

${ }^{14}$ If someone was in the Netherlands but did not have income, they would be entered in this file as a zero-income person.
} 


\subsection{Usage of antidepressants relative to childbirth}

To determine the usage of antidepressants relative to childbirth, and particularly after birth, we use a special prescription drug file that was compiled for us by Statistics Netherlands and that has information about all antidepressant prescriptions dispensed at retail pharmacies (ATC-4 category N06A) for 2006 to 2018. We set up a panel for our sample where $t=0$ reflects the birth month of the child. We then look to see whether the mother had at least one dispensed prescription for antidepressants in the 24 months before or the 30 months after the birth. The mean number of days between filled prescriptions for antidepressants is 32 days in our data, ${ }^{15}$ which implies that antidepressant scripts for are usually renewed every 3-4 weeks.

We distinguish between women who took antidepressants prior to pregnancy and those who did not. We define those with no use before birth as individuals who were not taking any antidepressants in the 10 to 24 months preceding childbirth (95.4\%); “ever takers” are women who were dispensed at least one script for antidepressants in this before-birth time period (3.1\%); and "always takers" are women who were dispensed a script for antidepressants in at least seven months of the fifteen months before the likely conception (1.5\%).

Figure 2a shows antidepressant usage relative to childbirth for these three groups. The figure shows that antidepressant usage is quite constant in the months prior to the likely conception date (shown by the vertical first red line). It declines when the woman finds out that she is pregnant (2-3 months after the likely conception date) and remains at a lower level throughout the pregnancy. This dip suggests that many women go off antidepressants during pregnancy. The proportion of women receiving antidepressants increases again after childbirth. Usage is highest

\footnotetext{
${ }^{15}$ The mean number of days between filled antidepressant prescriptions over the 2006 to 2018 time period is 32 days, with a median of 23 days. The $10^{\text {th }}$ percentile is 7 days (hence weekly pick-up of antidepressants), and the $90^{\text {th }}$ percentile is 87 days (which would refer to a three-month supply).
} 
among always takers, somewhat lower for ever takers, and appears very low for never takers. However, this is partly a matter of scale. Figure $\mathbf{2 b}$ zooms in on those who did not take antidepressants in the period preceding (the likely) conception month. In this group take up ticks up slightly during pregnancy, and then increases greatly after the birth.

To make sure that we are looking at a comparable group of women when it comes to antidepressant use after pregnancy, we focus on women in the group with no use before birth, i.e. those who did not get a script for antidepressants in the 15 months prior to the likely conception of the child. This restriction gives us a final sample of 427,475 observations. Our main "treatment" measure of postpartum antidepressant use refers to whether the mother received at least one antidepressant script in the 1 to 10 months after giving birth, which includes 2.5 percent of the women in the final sample.

Figure 3a shows a plot of antidepressant use similar to Figure $\mathbf{2 b}$ except that women are broken into terciles based on the value of the instrument (prescribing intensity to women aged 46 to 65 in the year before birth). The figure shows that antidepressant use after childbirth is highest for mothers in the highest tercile (i.e. in areas with a lot of antidepressant prescribing to older women) and is lower for women in the middle and lowest terciles. To check that these differences are not caused by differences between the types of women who live in different areas, we first residualize antidepressant use by controlling for the wide range of individual-level background and postal code-level characteristics discussed above. These residuals are then plotted in Figure 3b. Although the differences between terciles become smaller, they show a very similar pattern. Hence, these figures suggest that our instrument does predict mothers' antidepressant use right after childbirth. 
While Figure 3 shows that the instrument is predictive, it cannot show that the instrument is valid in the sense that it affects outcomes only through its effects on prescribing for postpartum depression. In an effort to further probe this question, we present a "balance check" in Figure 4. Figure 4 shows that once characteristics of postal codes and area-level fixed effects are accounted for, the individual-level characteristics of the mothers in our sample do not predict the instrument at their postal code in the year before birth.

\subsection{Maternal outcomes}

We examine several sets of maternal outcomes. First, we ask whether the usage of antidepressants in months 1 to 10 after birth affects the probability of taking antidepressants 11 to 20 and 21 to 30 months after birth. For 2011 to 2016 information on whether there are spells of specialized mental health care (GGZDBCTRAJECTENBUS) are available, which serves as an indicator of having a more serious mental health condition. Indicators are created for receiving treatment for a severe diagnosis in the year (1 to 10 months), 2 years (11 to 20 months), and 3 years (21 to 30 months) after birth. Given that the births in the sample occurred between 2008 and 2016 and the data in this file is available from 2011 to 2016, this outcome is not available for every birth in the sample so the sample size is smaller (Max $\mathrm{N}=254,489)$ for these outcomes.

The labor market outcomes of the parents come from the Dutch tax authorities and are located in the personal income files (IPI and INPATAB). These files include a measure of primary annual income which contains each individual's gross annual income from employment (including payments received for work done outside the scope of the contract and imputed values for the private use of a car). The files also contain a measure of annual income for self-employed individuals. The values of personal primary income for mothers and fathers are calculated for the three years prior and post birth of the first child, and the measure is corrected for inflation given 
that the births occur between 2008 and 2016. ${ }^{16}$ We also create a measure for positive income in any year -- an individual is assumed to be out of the labor force if income is zero. The sample is restricted to mothers for whom income can be observed in the 2 calendar years before birth, the calendar year of childbirth, and the 3 calendar years after the birth. ${ }^{17}$

In order to examine effects on family formation, we create indicators using the address file to see if children lived with their parents or in the same municipality as their parents in the years after childbirth. We also ask how antidepressants influence subsequent fertility, focusing on the probability of giving birth within 24 months or within 30 months after the first birth.

Table A1 presents means of all of the variables including outcomes, area-level controls, and individual-level controls. Column 1 shows the overall means, while the remaining columns break up the means by terciles of the instrument. The table shows that areas that are in the top tercile of prescribing to women 46 to 65 also have more prescribing to new mothers postpartum and that they have continued higher rates of prescribing to new mothers 11 to 20 months and 21 to 30 months after birth. Women in these areas are also more likely to be receiving specialized psychiatric treatment during these time periods. Women in high-prescribing areas are less likely to have a second birth within 30 months and are less likely to have positive income in the three years after birth. Fathers are also less likely have positive income and both mothers and fathers have lower incomes after the birth in the high-prescribing areas. It is also less likely that fathers and children are living at the same address or in the same municipality in the years after the birth.

\footnotetext{
${ }^{16}$ Some individuals have income that is smaller than zero, this is caused by individuals who are self-employed and for whom income is often equal to the profits made by their company (applies to less than $1 \%$ of observations). We set these negative values to zero.

${ }^{17}$ Fathers' income in all of these years is observed for $94.0 \%$ of births, so in the appendix, where we examine fathers' income as an outcome, the sample size is slightly lower. Information on income is missing if individuals did not report income to the tax authorities in a given year. It is likely that most of these individuals were absent from the Netherlands in that year since even zero-income people in the Netherlands would report to the tax authorities. Also, for some individuals, income is unknown if they receive income from abroad but live in the Netherlands, if they do not have to pay Dutch taxes.
} 
However, the individual-level and area-level controls presented in the rest of the table indicate that women in high-prescribing areas are systematically more disadvantaged along every dimension. For example, they are more likely to have children at a young age and less likely to have a Dutch background. Mothers and fathers are also less likely to work and have lower income in the two years prior to the birth. The areas they live in also have these characteristics. Hence, the apparently negative outcomes following postpartum antidepressant prescribing could reflect the fact that more disadvantaged women are more likely to receive prescriptions for antidepressants because they live in high-prescribing areas.

\section{Results}

The first row of Table 2 shows OLS estimates of the relationship between postpartum antidepressant use, future antidepressant use, and future receipt of specialized mental health care. The estimates all suggest that postpartum antidepressant use has large effects. For example, women who were taking antidepressants in the 1 to 10 months after birth have a 39 percentage points higher probability of taking them 21 to 30 months after the birth. The first stage regression is shown in the first column of Table 2 . The instrument is strongly statistically significant suggesting that a one standard deviation change in the instrument $(0.007)^{18}$ would be associated with a 5.5 percent increase $((0.007 \times 0.197) / 0.025)$ in the probability that a new mother receives postpartum antidepressants.

The instrumental variable estimates shown in Panel A2 of Table 2 indicate slightly larger effects of postpartum antidepressant use on future antidepressant use-the probability that a mother is still taking them 11 to 20 months after the birth after birth now rises by 60.9 percentage

\footnotetext{
${ }^{18}$ The mean value of the instrument in our sample is 0.022 , with a standard deviation of 0.007 .
} 
points, and the probability that the mother is still taking them 21 to 30 months after the birth now rises by 68.7 percentage points. This implies that a one standard deviation increase in the instrument leads to 3.8\% higher long-term use of antidepressants in the 21 to 30 months after birth (0.687 x 0.055). However, the effects on future use of specialized mental health care are no longer statistically significant.

The weak instruments problem is a well-known problem in instrumental variables estimation. The first stage F-statistics are larger than ten, and hence conform to the rule-of-thumb that is often used. We also report Anderson-Rubin (AR) confidence sets that are robust to weak instruments for cases with only one instrument as recommended by Andrews et al. (2019). ${ }^{19}$ These confidence bounds, reassuringly, do not include zero for antidepressant use in the three years after the birth.

The remainder of Table 2 breaks the sample into the top quartile by pre-pregnancy family income (calculated as the sum of paternal and maternal income over the two calendar years prior to the birth year), and the remaining 75 percent. The first stage is stronger in the top quartile than in the rest of the sample as evidenced by both the size of the estimated coefficient and the first stage F-statistic. For women in the top quartile of the pre-pregnancy income distribution, a one standard deviation increase in the instrument leads to a 18.0 percent increase $((0.007 \mathrm{x}$ 0.334)/0.013) in the probability of receiving antidepressants in the 1 to 10 months after childbirth.

The fact that area-level prescribing propensity is so much more predictive of postpartum antidepressant use in the high-income sample may indicate that these women are more likely to be in the "marginal" group that is treated in high prescribing areas but not in low prescribing areas.

\footnotetext{
${ }^{19}$ We calculate these Anderson-Rubin (AR) confidence bounds using the Stata implementation by Sun (2018).
} 
In turn, this finding is consistent with the finding in the literature that higher income is protective against postpartum depression (Williams and Cheadle, 2016).

The instrumental variable estimates of the effects of postpartum antidepressant use on future antidepressant use are quite similar in terms of the point estimates, but the effects of a one standard deviation increase in the instrument on long term use of antidepressants are about three times larger because of the more predictive first stage. However, the instrumental variables estimate of the effect of postpartum antidepressant use on specialized mental health care after birth is still not statistically significant for either group.

Table 3 shows very similar patterns for maternal labor force outcomes. The OLS estimates suggest that postpartum antidepressant use is strongly associated with reductions in the probability of labor force participation and in lower earnings conditional on being employed. For example, by three calendar years after the birth, the probability of having positive personal income has dropped by 10 percentage points (on a baseline of 90 percent employment) while earnings conditional on employment are down 20 percent. However, when we turn to the instrumental variables estimates, these effects are not statistically significant, except in the first full calendar year after birth. The split by income shows that the negative effects on employment income in the first year are driven by the bottom $75 \%$ of the sample and are not observed in the top quartile of the income distribution. Possibly, high income women with PPD are better able to negotiate accommodations with their employers. In sum, while there is evidence of a short-term effect, there is little evidence here that postpartum antidepressant use hurts longer-term maternal employment outcomes.

Table 4 explores the effects of postpartum antidepressant use on family structure. The OLS estimates suggest that maternal postpartum antidepressant use has modest negative effects on 
the probability that the father lives at the same address or in the same municipality as the child. There also appears to be a negative effect on the probability of a second birth within 30 months. However, once again, when we instrument for individual postpartum antidepressant use, most of these effects become statistically insignificant, and the effects on whether the father is living with the child generally turn positive. We find no evidence that the effects are different by prepregnancy household income.

Tables A2 and A3 show some additional outcomes: The effects of maternal postpartum antidepressant use on father's employment outcomes, and the effects on whether the mother lives with the child. In all cases, the OLS estimates suggest negative impacts while the IV estimates are statistically insignificant.

In Table A4 we report additional estimates focusing only on mothers with a Dutch background (about $87 \%$ of our sample). The first stage results are somewhat stronger in the sample of Dutch mothers: A one standard deviation increase in the instrument leads to a 5.8 percent higher probability that the mother uses antidepressants in the 10 months after birth. Also, the IV coefficient on antidepressant use 11-20 months after birth is slightly larger as compared to the baseline estimates. $^{20}$

In the remaining panels of Table A4, the sample is split by maternal age at first birth. Panel B focuses on women above the median (29.4 or older), and Panel C focuses on women with below median age at birth. The OLS results on subsequent antidepressant use and specialized mental health care use are stronger for older mothers as compared to younger mothers. However, this appears to be explained by selection into antidepressant use. The IV-estimates for subsequent antidepressant use are not statistically significant in the sample of older women. The estimated

\footnotetext{
${ }^{20}$ The IV estimates for the other outcome variables are not significantly different from zero and are available by request.
} 
effect of postpartum anti-depressant use is large and statistically significant in the sample of younger women. This result suggests that particularly for young women, it may be difficult to stop taking antidepressants after starting to take them postpartum.

Moreover, we also find that younger women are significantly less likely to work in the first calendar year after giving birth (with a point estimate -1.871 and a standard deviation of 0.772 , not reported), which is about 2.3 times larger than our baseline estimate. However, we do not see significant effects in the two to three years after birth, so the impact on employment outcomes for this group may be fleeting.

Finally, Table 5 presents some additional estimates to check the robustness of our estimates. We first focus on postal codes that have 3 or fewer GP practices. In areas with few GP practices, a mother is more constrained in her choice of providers, and if our instrument works well it is expected to be more predictive in this subsample. ${ }^{21}$ The tables show the first stage and two outcomes: subsequent antidepressant usage and receiving specialized mental health care after birth. ${ }^{22}$ As predicted, the first stage results and the estimated effects on subsequent antidepressant use for these 1,548 postal codes are somewhat larger than in the full sample. The table also provides a robustness check including both first and second births, which yields a larger sample of more than 760,000 births. These estimates from this larger sample are similar to the baseline estimates.

\footnotetext{
${ }^{21}$ The mothers in our sample have, on average, access to 2.9 GP practices in their postal code of residence over the 2009 to 2016 time period.

${ }^{22}$ The results for the remaining outcome variables are not reported but are similar to our baseline estimates (available on request).
} 


\section{Discussion and Conclusions}

Women treated with antidepressants postpartum have different outcomes than other new mothers in many respects. In OLS regressions they are estimated to be more likely to remain on antidepressants after two to three years and are more likely to be treated by specialists for acute mental health problems. They are also less likely to return to work and earn less money conditional on working. Their children are less likely to be living with their fathers, or even to live in the same city as their fathers. Finally, these mothers are less likely to have a second birth within 30 months of a first birth.

However, instrumental variable estimates suggest that most of these negative associations between postpartum antidepressant treatment and outcomes are due to selection into antidepressant treatment. The women who are most likely to receive postpartum antidepressants are disadvantaged in every observable respect and also live in poorer places. When we control for this selection, most outcomes are not significantly affected by postpartum antidepressant use. The major exception is that women are still much more likely to be taking antidepressants two to three years later. This observation is consistent with a growing literature showing that it can be very difficult for patients to stop taking antidepressants, with some patients experiencing extended withdrawal symptoms that may mimic relapse into depression (Davies and Read, 2019).

Our estimates reflect the experience of the marginal patient—someone who would be prescribed antidepressants in a high-prescribing area, but who would not have received them in a low-prescribing neighborhood. These estimates are silent about the impact of prescribing on a patient who is so severely depressed that she would likely be treated with antidepressants in any neighborhood. However, the marginal patient is especially interesting if we are asking whether guidelines for prescribing should be stricter or looser. Bos, Hertzberg and Liberman (2021) argue 
that the marginal young male patient in Sweden is harmed by being diagnosed with a mental illness. In a different context, Alalouf et al. (2019) find that the marginal diabetes patient spends more money but is not in measurably better health six years after a diagnosis. ${ }^{23}$

Our estimates suggest that the marginal patient treated with postpartum antidepressants in the Netherlands receives little benefit from being treated and experiences some harm in that they are much more likely to end up taking antidepressants long-term. Since antidepressants do have side effects (such as weight gain and increases in blood sugar), such long-term use is not costless. While it is difficult to extrapolate these results to other health care settings, it is likely that places like the United States, where a much higher fraction of the population is being treated, are even further down the benefit-cost curve and that stricter guidelines for the prescription of antidepressant drugs could be beneficial.

${ }^{23}$ Persson, Qiu, and Rossin-Slater (2021) find that marginal diagnoses also have spillovers onto other family members, increasing their probability of being diagnosed. 
Figure 1: Geographic variation in new uses of antidepressants for women aged 45-65, per 1000, the Netherlands, 2009 and 2016

(a) 2009

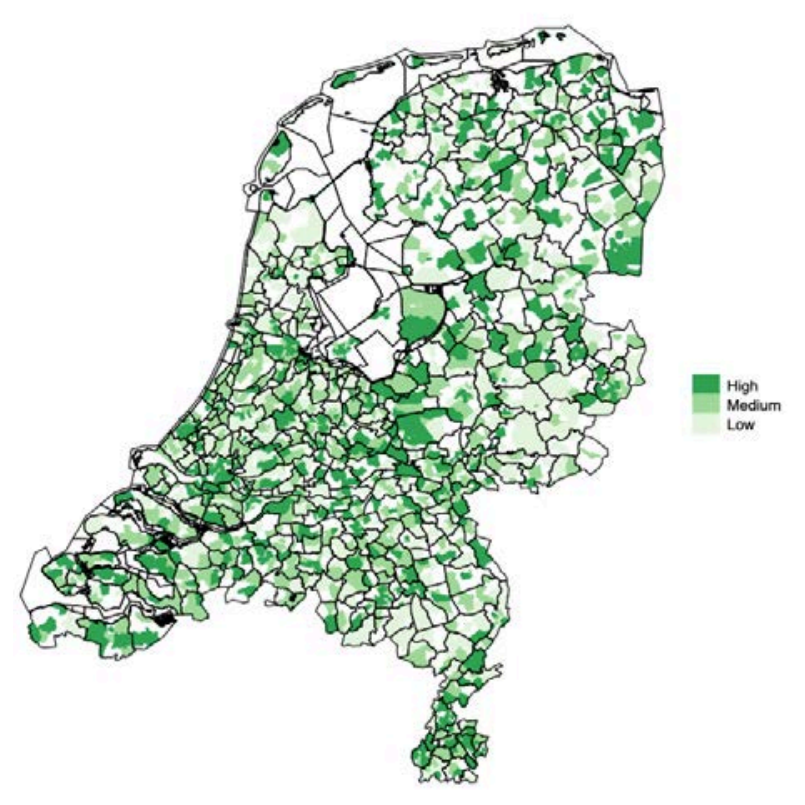

(b) 2016

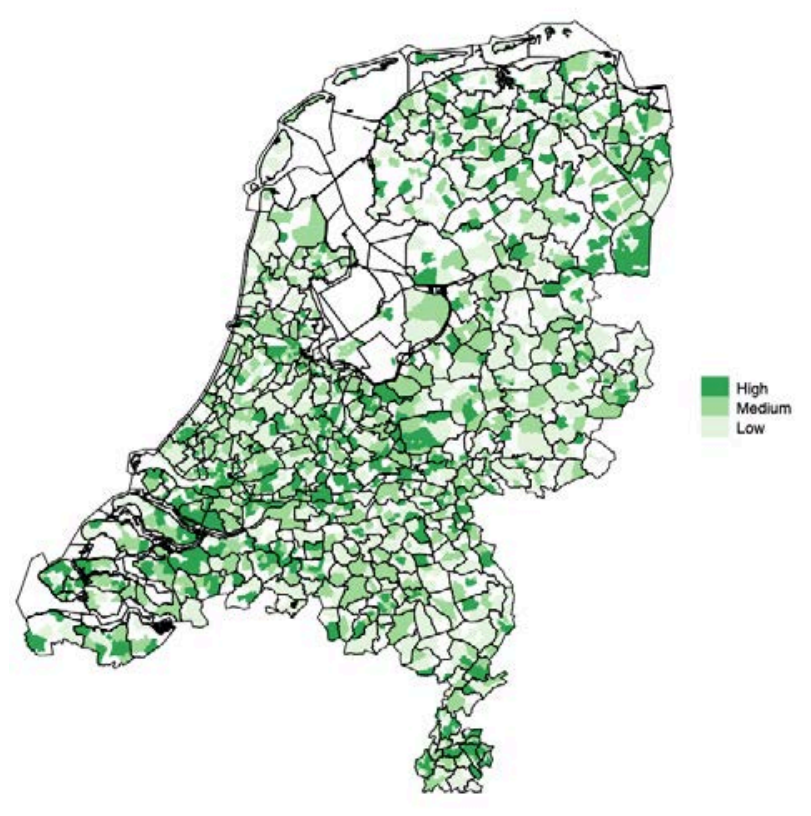

Notes: The maps plot the number of new antidepressant patients among women aged 46-65 in each 4-digit postal code $(2,001)$ that has inhabitants in all years 2006 to 2018 and that has at least one GP practice in all years 20092016. Prescribing measure plotted for 2009 and 2016, and postal codes are split up in terciles of this measure of prescribing intensity. The black lines on the maps show the 2016 municipality boundaries. 


\section{Figure 2: Antidepressant usage relative to childbirth}

(a) By antidepressant use before birth

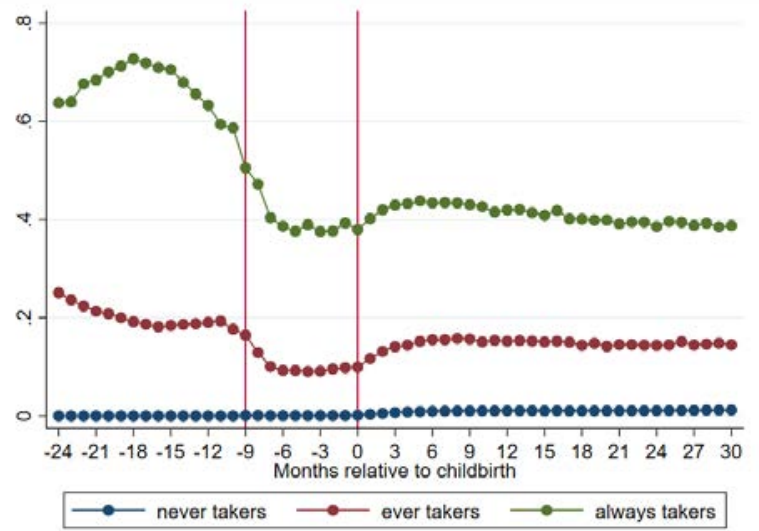

(b) No use before birth

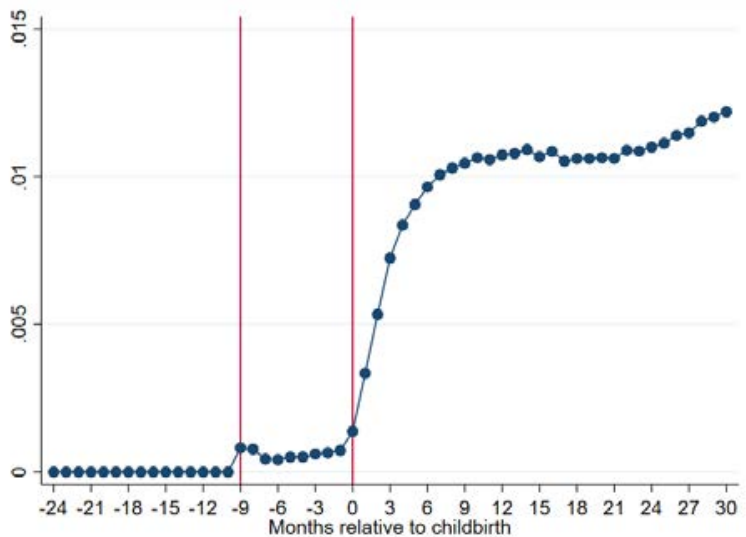

Notes: Panel (a) is based on the sample of first births $(\mathrm{N}=448,226)$, and splits the sample into no use before birth (no prescriptions in the 10-24 months prior to childbirth), "ever takers" (those with at least one prescription in the 10-24 months prior to childbirth, and "always takers" (those with prescriptions in more than 50\% of the $10-24$ months prior to childbirth). Panel (b) focuses on those with no use before birth $(\mathrm{N}=427,475)$. 
Figure 3: Antidepressant usage by area-level prescribing intensity

(a) Raw data

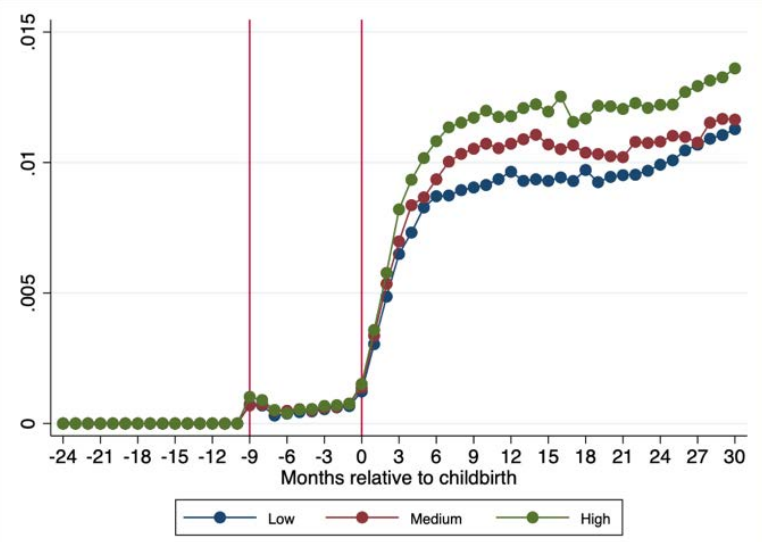

(b) Residualized data

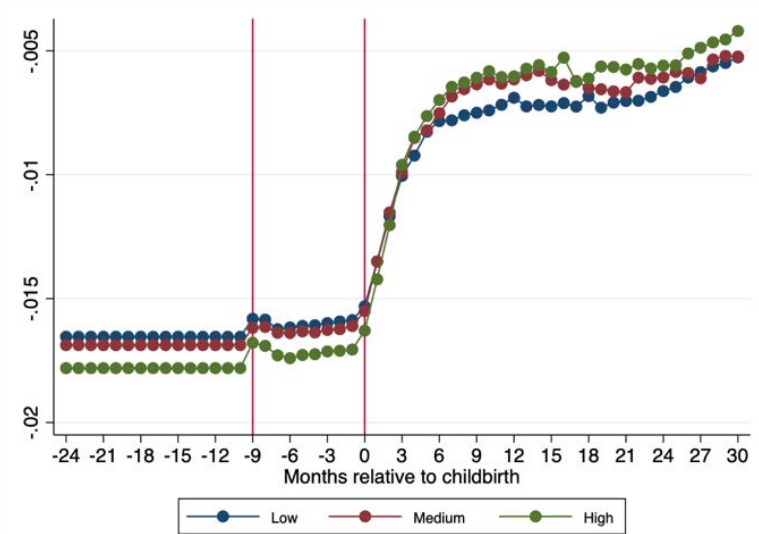

Notes: Panel (a) reports proportion of individuals dispensing a script for antidepressants at a pharmacy in each month relative to childbirth for first births and never users $(\mathrm{N}=427,475)$. It splits the sample into three groups depending on terciles of the number of new antidepressant patients per 1,000 in the woman's postal code of residence in the year prior to giving birth (our instrument). Panel (b) plots the residuals after controlling for the wide range of individuallevel characteristics and postal code level characteristics as mentioned in the empirical strategy. 
Figure 4: Balance check: Do individual characteristics predict the instrument?

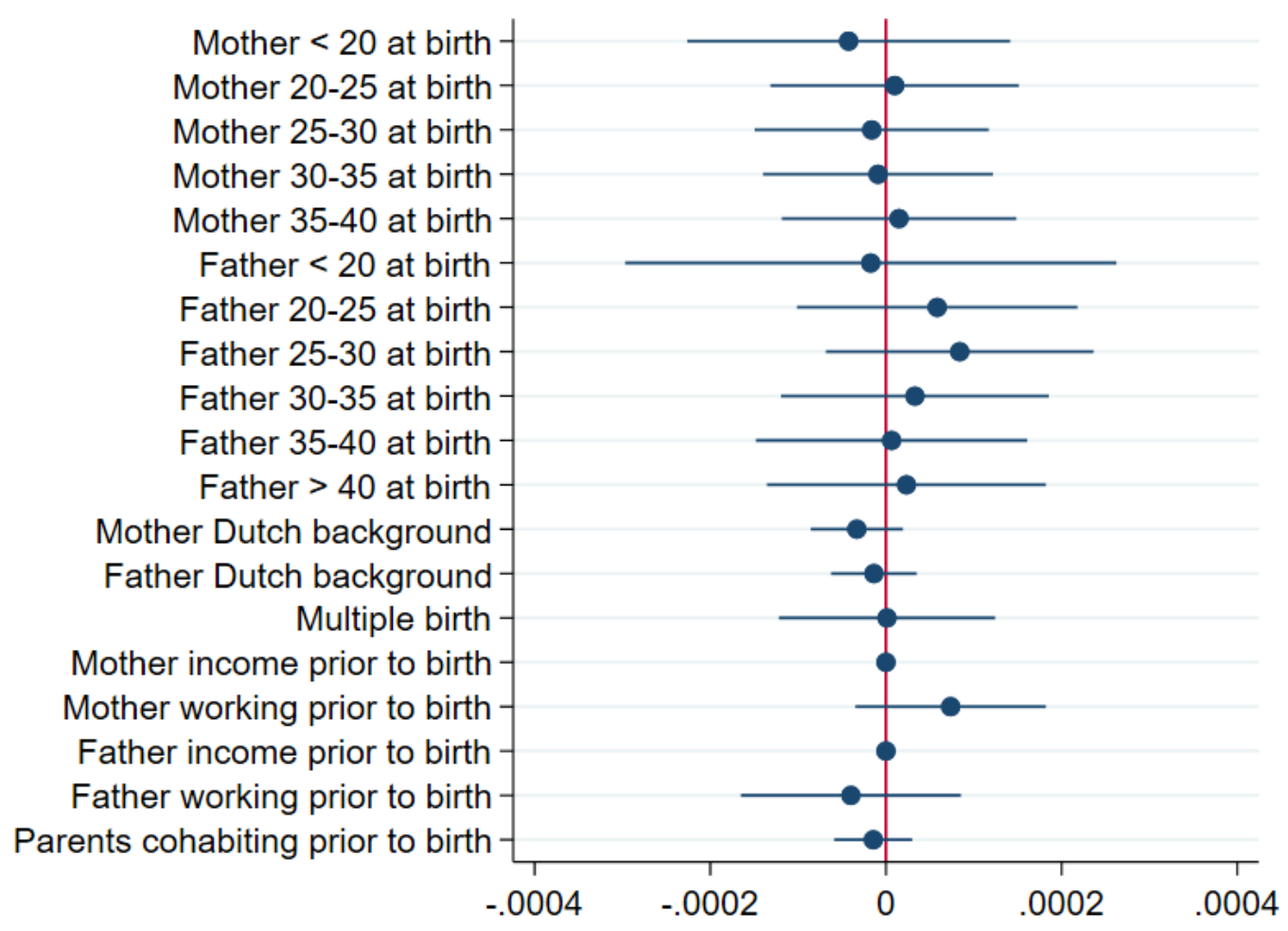

Notes: This figure plots the coefficients and 95\% confidence intervals from a balance check in which we regress the value of the instrument for each individual $(\mathrm{N}=427,475)$ on their individual-level characteristics (plotted), and include the postal-4 controls, and (481) area-level fixed effects, standard errors are clustered at the area level. 
Table 1: Correlates of instrument with postal code characteristics, 2016

\section{(1)}

(2)

(3)

(4)

(5)

(6)

(1) New female patients 45-65 1.0000

(2) New female patients 15-45 $\quad 0.3849 \quad 1.0000$

(3) Total population

$\begin{array}{lll}0.1457 & 0.0386 & 1.0000\end{array}$

(4) \% population Dutch

$\begin{array}{llll}-0.3532 & -0.1347 & -0.4584 & 1.0000\end{array}$

(5) \% low income HHs

$0.4023 \quad 0.3175$

0.2372

$-0.6113$

1.0000

(6) \% welfare recipients

$0.4206 \quad 0.3990$

0.2335

$-0.6020$

0.8207

1.0000

Notes: The measures of new antidepressant patients and total population at the 4-digit postal code level are calculated by the authors, and the measures for 2016 are used to calculate the correlations. The postal code characteristics come from Statistics Netherlands (in Dutch: Kerncijfers per postcode) and are shown for 2016. 
Table 2: First stage, subsequent antidepressant use, and future specialized mental health care

\begin{tabular}{|c|c|c|c|c|c|c|}
\hline & \multicolumn{3}{|c|}{ Antidepressant use } & \multicolumn{3}{|c|}{ Specialized mental health care } \\
\hline & $\begin{array}{l}\text { Mo } 1 \text { to } 10 \\
\text { (1) }\end{array}$ & $\begin{array}{c}\text { Mo } 11 \text { to } \\
20 \\
(2)\end{array}$ & $\begin{array}{c}\text { Mo } 21 \text { to } \\
30 \\
(3)\end{array}$ & $\begin{array}{l}\text { Mo } 1 \text { to } 10 \\
\text { (4) }\end{array}$ & $\begin{array}{c}\text { Mo } 11 \text { to } \\
20 \\
(5)\end{array}$ & $\begin{array}{c}\text { Mo } 21 \text { to } \\
30 \\
(6)\end{array}$ \\
\hline \multicolumn{7}{|l|}{ Panel A1: OLS } \\
\hline AD 1-10 mo after birth & & $\begin{array}{l}0.573^{* *} \\
(0.005)\end{array}$ & $\begin{array}{l}0.390 * * \\
(0.005)\end{array}$ & $\begin{array}{l}0.401^{* *} \\
(0.008)\end{array}$ & $\begin{array}{l}0.363^{* *} \\
(0.008)\end{array}$ & $\begin{array}{l}0.279 * * \\
(0.008)\end{array}$ \\
\hline \multicolumn{7}{|l|}{ Panel A2: 2SLS } \\
\hline New patients $45-65$ & $\begin{array}{l}0.197 * * \\
(0.050)\end{array}$ & & & & & \\
\hline AD 1-10 mo after birth & & $\begin{array}{l}0.609 * * \\
(0.218)\end{array}$ & $\begin{array}{l}0.687 * * \\
(0.248)\end{array}$ & $\begin{array}{c}0.064 \\
(0.332)\end{array}$ & $\begin{array}{l}-0.005 \\
(0.342)\end{array}$ & $\begin{array}{c}0.193 \\
(0.401)\end{array}$ \\
\hline $\begin{array}{l}\text { Weak IV 95\% AR } \\
\text { confidence set }\end{array}$ & & $\begin{array}{l}{[0.111 ;} \\
1.063]\end{array}$ & $\begin{array}{c}{[0.221 ;} \\
1.299]\end{array}$ & $\begin{array}{c}{[-0.692 ;} \\
0.689]\end{array}$ & $\begin{array}{c}{[-0.919} \\
0.637]\end{array}$ & $\begin{array}{c}{[-0.800} \\
1.107]\end{array}$ \\
\hline Mean outcome & 0.025 & 0.028 & 0.030 & 0.045 & 0.044 & 0.043 \\
\hline F-statistic 1st stage & 15.23 & 15.23 & 15.23 & 16.28 & 13.23 & 10.74 \\
\hline Observations & 427,475 & 427,475 & 427,475 & 254,489 & 214,617 & 174,249 \\
\hline \multicolumn{7}{|c|}{ Panel B1: OLS Top 25\% income } \\
\hline AD 1-10 mo after birth & & $\begin{array}{l}0.612^{* *} \\
(0.013)\end{array}$ & $\begin{array}{l}0.421^{* *} \\
(0.013)\end{array}$ & $\begin{array}{c}0.438 * * \\
(0.017) \\
\end{array}$ & $\begin{array}{l}0.348^{* *} \\
(0.018)\end{array}$ & $\begin{array}{l}0.250 * * \\
(0.018)\end{array}$ \\
\hline \multicolumn{7}{|c|}{ Panel B2: 2SLS Top 25\% income } \\
\hline New patients $45-65$ & $\begin{array}{c}0.334^{* *} \\
(0.071)\end{array}$ & & & & & \\
\hline AD 1-10 mo after birth & & $\begin{array}{l}0.612 * * \\
(0.164)\end{array}$ & $\begin{array}{l}0.560^{*} \\
(0.221)\end{array}$ & $\begin{array}{c}0.095 \\
(0.405)\end{array}$ & $\begin{array}{c}0.245 \\
(0.422)\end{array}$ & $\begin{array}{c}0.661 \\
(0.406)\end{array}$ \\
\hline $\begin{array}{l}\text { Weak IV 95\% AR } \\
\text { confidence set }\end{array}$ & & $\begin{array}{r}{[0.272} \\
0.953]\end{array}$ & $\begin{array}{l}{[0.145} \\
1.018]\end{array}$ & $\begin{array}{c}{[-0.908} \\
0.937]\end{array}$ & $\begin{array}{c}{[-1.051} \\
1.123]\end{array}$ & $\begin{array}{c}{[-0.022} \\
1.825]\end{array}$ \\
\hline Mean outcome & 0.013 & 0.014 & 0.016 & 0.028 & 0.026 & 0.026 \\
\hline F-statistic $1^{\text {st }}$ stage & 21.88 & 21.88 & 21.88 & 11.86 & 8.33 & 12.68 \\
\hline Observations & 106,868 & 106,868 & 106,868 & 72,432 & 59,442 & 46,670 \\
\hline \multicolumn{7}{|c|}{ Panel C1: OLS Bottom 75\% income } \\
\hline AD 1-10 mo after birth & & $\begin{array}{l}0.566 * * \\
(0.006) \\
\end{array}$ & $\begin{array}{l}0.385^{* *} \\
(0.006) \\
\end{array}$ & $\begin{array}{l}0.393^{* *} \\
(0.008) \\
\end{array}$ & $\begin{array}{l}0.365^{* *} \\
(0.009) \\
\end{array}$ & $\begin{array}{c}0.283^{* *} \\
(0.009) \\
\end{array}$ \\
\hline \multicolumn{7}{|c|}{ Panel C2: 2SLS Bottom 75\% income } \\
\hline New patients $45-65$ & $\begin{array}{c}0.162 * * \\
(0.060)\end{array}$ & & & & & \\
\hline AD 1-10 mo after birth & & $\begin{array}{c}0.646 \\
(0.334)\end{array}$ & $\begin{array}{l}0.750^{*} \\
(0.371)\end{array}$ & $\begin{array}{c}0.063 \\
(0.472)\end{array}$ & $\begin{array}{l}-0.088 \\
(0.459)\end{array}$ & $\begin{array}{l}-0.039 \\
(0.612)\end{array}$ \\
\hline $\begin{array}{l}\text { Weak IV 95\% AR } \\
\text { confidence set }\end{array}$ & & $\begin{array}{c}{[-0.314 ;} \\
1.540]\end{array}$ & $\begin{array}{l}{[0.052 ;} \\
2.256]\end{array}$ & $\begin{array}{c}{[-1.291 ;} \\
1.137]\end{array}$ & $\begin{array}{r}{[-1.680} \\
0.867]\end{array}$ & $\begin{array}{c}{[-4.703 ;} \\
1.475]\end{array}$ \\
\hline Mean outcome & 0.029 & 0.033 & 0.035 & 0.051 & 0.050 & 0.049 \\
\hline F-statistic $1^{\text {st }}$ stage & 7.16 & 7.16 & 7.16 & 8.23 & 7.42 & 4.74 \\
\hline Observations & 320,607 & 320,607 & 320,607 & 182,057 & 155,175 & 127,579 \\
\hline $\begin{array}{l}\text { Votes: Panels B and C split the } \\
\text { rior to first birth). The antide } \\
\text { lispensed at least one script fo }\end{array}$ & mple up by $\mathrm{h}$ & ehold incom & ean of the su & f maternal anc & equal to one & $\begin{array}{l}\text { the two year } \\
\text { e woman was } \\
\text { for receipt o }\end{array}$ \\
\hline
\end{tabular}


Table 3: Labor market outcomes for mothers after birth

\begin{tabular}{|c|c|c|c|c|c|c|}
\hline & \multicolumn{3}{|c|}{ Positive income } & \multicolumn{3}{|c|}{ Log earnings } \\
\hline & $\begin{array}{l}\text { Y1 } \\
(1)\end{array}$ & $\begin{array}{l}\mathrm{Y} 2 \\
(2)\end{array}$ & $\begin{array}{l}\text { Y3 } \\
\text { (3) }\end{array}$ & $\begin{array}{l}\text { Y1 } \\
(4)\end{array}$ & $\begin{array}{l}\mathrm{Y} 2 \\
(5)\end{array}$ & $\begin{array}{l}\text { Y3 } \\
(6)\end{array}$ \\
\hline \multicolumn{7}{|l|}{ Panel A1: OLS } \\
\hline $\begin{array}{l}\text { AD 1-10 mo after } \\
\text { Birth }\end{array}$ & $\begin{array}{c}-0.092 * * \\
(0.004)\end{array}$ & $\begin{array}{c}-0.101^{* *} \\
(0.004)\end{array}$ & $\begin{array}{c}-0.104^{* *} \\
(0.004)\end{array}$ & $\begin{array}{c}-0.141^{* *} \\
(0.012)\end{array}$ & $\begin{array}{c}-0.159^{* *} \\
(0.011) \\
\end{array}$ & $\begin{array}{c}-0.205^{* *} \\
(0.011)\end{array}$ \\
\hline \multicolumn{7}{|l|}{ Panel A2: 2SLS } \\
\hline $\begin{array}{l}\text { AD 1-10 mo after } \\
\text { Birth } \\
\text { Weak IV 95\% AR } \\
\text { confidence set } \\
\text { Mean outcome } \\
\text { F-statistic 1st stage } \\
\text { Observations } \\
\end{array}$ & $\begin{array}{c}-0.821^{*} \\
(0.406) \\
{[-1.907} \\
-0.137] \\
0.910 \\
15.23 \\
427,475 \\
\end{array}$ & $\begin{array}{c}-0.089 \\
(0.420) \\
{[-0.962} \\
0.868] \\
0.905 \\
15.23 \\
427,475 \\
\end{array}$ & $\begin{array}{c}-0.021 \\
(0.405) \\
{[-0.862} \\
0.901] \\
0.900 \\
15.23 \\
427,475 \\
\end{array}$ & $\begin{array}{c}1.042 \\
(1.213) \\
{[-1.238} \\
4.283] \\
€ 30,590 \\
13.09 \\
386,973 \\
\end{array}$ & $\begin{array}{c}0.305 \\
(1.331) \\
{[-2.462 ;} \\
3.337] \\
€ 31,947 \\
13.72 \\
384,930 \\
\end{array}$ & $\begin{array}{c}-0.416 \\
(1.329) \\
{[-3.179 ;} \\
2.347] \\
€ 33,332 \\
16.93 \\
382,611 \\
\end{array}$ \\
\hline \multicolumn{7}{|c|}{ Panel B1: OLS Top 25\% income } \\
\hline $\begin{array}{l}\text { AD 1-10 mo after } \\
\text { Birth }\end{array}$ & $\begin{array}{c}-0.028^{* *} \\
(0.006)\end{array}$ & $\begin{array}{c}-0.034 * * \\
(0.007)\end{array}$ & $\begin{array}{c}-0.045^{* *} \\
(0.008)\end{array}$ & $\begin{array}{c}-0.063 * * \\
(0.022)\end{array}$ & $\begin{array}{c}-0.094^{* *} \\
(0.019)\end{array}$ & $\begin{array}{c}-0.146^{* *} \\
(0.023)\end{array}$ \\
\hline \multicolumn{7}{|c|}{ Panel B2: 2SLS Top 25\% income } \\
\hline $\begin{array}{l}\text { AD 1-10 mo after } \\
\text { Birth } \\
\text { Weak IV 95\% AR } \\
\text { confidence set } \\
\text { Mean outcome } \\
\text { F-statistic } 1^{\text {st }} \text { stage } \\
\text { Observations } \\
\end{array}$ & $\begin{array}{c}-0.179 \\
(0.269) \\
{[-0.791} \\
0.327] \\
0.978 \\
21.88 \\
106,868 \\
\end{array}$ & $\begin{array}{c}0.329 \\
(0.321) \\
{[-0.276} \\
0.997] \\
0.972 \\
21.88 \\
106,868 \\
\end{array}$ & $\begin{array}{c}0.021 \\
(0.303) \\
{[-0.609} \\
0.591] \\
0.968 \\
21.88 \\
106,868 \\
\end{array}$ & $\begin{array}{c}0.172 \\
(1.062) \\
{[-1.825} \\
2.591] \\
€ 48,670 \\
18.89 \\
104,146 \\
\end{array}$ & $\begin{array}{c}-0.388 \\
(1.213) \\
{[-2.910} \\
2.374] \\
€ 50,504 \\
16.39 \\
103,464 \\
\end{array}$ & $\begin{array}{c}0.687 \\
(1.554) \\
{[-2.236} \\
4.533] \\
€ 52,429 \\
14.11 \\
102,926 \\
\end{array}$ \\
\hline \multicolumn{7}{|c|}{ Panel C1: OLS Bottom 75\% income } \\
\hline $\begin{array}{l}\text { AD 1-10 mo after } \\
\text { Birth }\end{array}$ & $\begin{array}{c}-0.096 * * \\
(0.004)\end{array}$ & $\begin{array}{c}-0.106 * * \\
(0.004)\end{array}$ & $\begin{array}{c}-0.107 * * \\
(0.004)\end{array}$ & $\begin{array}{c}-0.131^{* *} \\
(0.012)\end{array}$ & $\begin{array}{c}-0.151^{* *} \\
(0.013)\end{array}$ & $\begin{array}{c}-0.195 * * \\
(0.013)\end{array}$ \\
\hline \multicolumn{7}{|c|}{ Panel C2: 2SLS Bottom 75\% income } \\
\hline $\begin{array}{l}\text { AD 1-10 mo after } \\
\text { Birth } \\
\text { Weak IV 95\% AR } \\
\text { confidence set } \\
\text { Mean outcome } \\
\text { F-statistic } 1^{\text {st }} \text { stage } \\
\text { Observations }\end{array}$ & $\begin{array}{c}-1.331^{*} \\
(0.665) \\
{[-4.557} \\
-0.344] \\
0.887 \\
7.16 \\
320,607\end{array}$ & $\begin{array}{c}-0.473 \\
(0.599) \\
{[-2.428} \\
0.890] \\
0.883 \\
7.16 \\
320,607\end{array}$ & $\begin{array}{c}-0.196 \\
(0.599) \\
{[-1.915 ;} \\
1.403] \\
0.878 \\
7.16 \\
320,607\end{array}$ & $\begin{array}{c}0.229 \\
(1.837) \\
{[-5.773 ;} \\
6.594] \\
€ 23,933 \\
5.64 \\
282,827\end{array}$ & $\begin{array}{c}-0.321 \\
(1.845) \\
{[-6.348 ;} \\
4.245] \\
€ 25,125 \\
6.84 \\
281,466\end{array}$ & $\begin{array}{c}-1.921 \\
(1.774) \\
{[-7.363 ;} \\
1.415] \\
€ 26,304 \\
9.71 \\
279,685\end{array}$ \\
\hline
\end{tabular}

Notes: Panels B and C split the sample up by household income (mean of the sum of maternal and paternal income in the two years prior to first birth). Positive income is a dummy variable and indicates that an individual had income greater than zero in the full calendar years after the birth year (Y1-Y3). Log earnings conditional on employment (after an inflation correction) is also reported for the three years after the birth year (Y1-Y3). All specifications include arealevel fixed effects, year of birth fixed effects, individual controls and postal code level controls. Robust standard errors are clustered at the area level and are shown in parentheses. ${ }^{* *} \mathrm{p}<0.01,{ }^{*} \mathrm{p}<0.05$. 
Table 4: Family formation

\begin{tabular}{|c|c|c|c|c|c|c|c|}
\hline & \multicolumn{3}{|c|}{ Father lives at same address } & \multicolumn{3}{|c|}{ Father lives in same muni } & \multirow{2}{*}{$\begin{array}{c}2^{\text {nd }} \text { birth } \\
<30 \text { mo } \\
(7)\end{array}$} \\
\hline & $\begin{array}{l}\mathrm{Y} 1 \\
(1)\end{array}$ & $\begin{array}{l}\mathrm{Y} 2 \\
(2)\end{array}$ & $\begin{array}{l}\text { Y3 } \\
\text { (3) }\end{array}$ & $\begin{array}{l}\text { Y1 } \\
(4)\end{array}$ & $\begin{array}{l}\mathrm{Y} 2 \\
(5)\end{array}$ & $\begin{array}{l}\text { Y3 } \\
(6)\end{array}$ & \\
\hline \multicolumn{8}{|l|}{ Panel A1: OLS } \\
\hline $\begin{array}{l}\text { AD 1-10 mo after } \\
\text { Birth }\end{array}$ & $\begin{array}{c}-0.019 * * \\
(0.003)\end{array}$ & $\begin{array}{c}-0.033^{* *} \\
(0.003)\end{array}$ & $\begin{array}{c}-0.042^{* *} \\
(0.003)\end{array}$ & $\begin{array}{c}-0.011^{* *} \\
(0.002)\end{array}$ & $\begin{array}{c}-0.018 * * \\
(0.002)\end{array}$ & $\begin{array}{c}-0.021^{* *} \\
(0.003)\end{array}$ & $\begin{array}{c}-0.137 * * \\
(0.004)\end{array}$ \\
\hline \multicolumn{8}{|l|}{ Panel A2: 2SLS } \\
\hline $\begin{array}{l}\text { AD 1-10 mo after } \\
\text { Birth } \\
\text { Weak IV 95\% AR } \\
\text { confidence set } \\
\text { Mean outcome } \\
\text { F-statistic 1st stage } \\
\text { Observations } \\
\end{array}$ & $\begin{array}{c}0.148 \\
(0.307) \\
{[-0.428} \\
0.907] \\
0.906 \\
15.23 \\
427,475 \\
\end{array}$ & $\begin{array}{c}0.309 \\
(0.351) \\
{[-0.351 ;} \\
1.246] \\
0.896 \\
15.23 \\
427,475 \\
\end{array}$ & $\begin{array}{c}0.512 \\
(0.382) \\
{[-0.131 ;} \\
1.608] \\
0.884 \\
15.23 \\
427,475 \\
\end{array}$ & $\begin{array}{c}0.201 \\
(0.270) \\
{[-0.308} \\
0.869] \\
0.934 \\
15.23 \\
427,475 \\
\end{array}$ & $\begin{array}{c}0.086 \\
(0.270) \\
{[-0.475} \\
0.702] \\
0.928 \\
15.23 \\
427,475 \\
\end{array}$ & $\begin{array}{c}0.174 \\
(0.305) \\
{[-0.400} \\
0.930] \\
0.922 \\
15.23 \\
427,475 \\
\end{array}$ & $\begin{array}{c}-0.256 \\
(0.752) \\
{[-1.819 ;} \\
1.456] \\
0.393 \\
15.23 \\
427,475 \\
\end{array}$ \\
\hline \multicolumn{8}{|c|}{ Panel B1: OLS Top 25\% income } \\
\hline $\begin{array}{l}\text { AD 1-10 mo after } \\
\text { Birth }\end{array}$ & $\begin{array}{c}-0.014^{* *} \\
(0.005)\end{array}$ & $\begin{array}{c}-0.025^{* *} \\
(0.006)\end{array}$ & $\begin{array}{c}-0.036 * * \\
(0.007)\end{array}$ & $\begin{array}{l}-0.003 \\
(0.004)\end{array}$ & $\begin{array}{l}-0.012 * \\
(0.005)\end{array}$ & $\begin{array}{c}-0.019 * * \\
(0.005)\end{array}$ & $\begin{array}{c}-0.205^{* *} \\
(0.012)\end{array}$ \\
\hline \multicolumn{8}{|c|}{ Panel B2: 2SLS Top 25\% income } \\
\hline $\begin{array}{l}\text { AD 1-10 mo after } \\
\text { Birth } \\
\text { Weak IV 95\% AR } \\
\text { confidence set } \\
\text { Mean outcome } \\
\text { F-statistic } 1^{\text {st }} \text { stage } \\
\text { Observations } \\
\end{array}$ & $\begin{array}{c}0.205 \\
(0.293) \\
{[-0.346} \\
0.871] \\
0.969 \\
21.88 \\
106,868 \\
\end{array}$ & $\begin{array}{c}0.094 \\
(0.270) \\
{[-0.468} \\
0.656] \\
0.969 \\
21.88 \\
106,868 \\
\end{array}$ & $\begin{array}{c}0.331 \\
(0.321) \\
{[-0.273} \\
1.063] \\
0.964 \\
21.88 \\
106,868 \\
\end{array}$ & $\begin{array}{c}0.443 \\
(0.257) \\
{[0.010 ;} \\
1.079] \\
0.982 \\
21.88 \\
106,868 \\
\end{array}$ & $\begin{array}{c}0.151 \\
(0.218) \\
{[-0.258} \\
0.647] \\
0.981 \\
21.88 \\
106,868 \\
\end{array}$ & $\begin{array}{c}0.383 \\
(0.255) \\
{[-0.045} \\
1.013] \\
0.979 \\
21.88 \\
106,868 \\
\end{array}$ & $\begin{array}{c}-1.143 \\
(0.926) \\
{[-3.435} \\
0.415] \\
0.477 \\
21.88 \\
106,868 \\
\end{array}$ \\
\hline \multicolumn{8}{|c|}{ Panel C1: OLS Bottom 75\% income } \\
\hline $\begin{array}{l}\text { AD 1-10 mo after } \\
\text { Birth }\end{array}$ & $\begin{array}{c}-0.018^{* *} \\
(0.003)\end{array}$ & $\begin{array}{c}-0.032 * * \\
(0.004)\end{array}$ & $\begin{array}{c}-0.041^{* *} \\
(0.004)\end{array}$ & $\begin{array}{l}-0.011^{* *} \\
(0.003)\end{array}$ & $\begin{array}{c}-0.018^{* *} \\
(0.003)\end{array}$ & $\begin{array}{c}-0.019 * * \\
(0.003)\end{array}$ & $\begin{array}{c}-0.123^{* *} \\
(0.005)\end{array}$ \\
\hline \multicolumn{8}{|c|}{ Panel C2: 2SLS Bottom 75\% income } \\
\hline $\begin{array}{l}\text { AD 1-10 mo after } \\
\text { Birth }\end{array}$ & $\begin{array}{l}-0.022 \\
(0.444)\end{array}$ & $\begin{array}{c}0.252 \\
(0.527)\end{array}$ & $\begin{array}{c}0.405 \\
(0.562)\end{array}$ & $\begin{array}{c}-0.023 \\
(0.391)\end{array}$ & $\begin{array}{l}-0.064 \\
(0.411)\end{array}$ & $\begin{array}{c}-0.090 \\
(0.457)\end{array}$ & $\begin{array}{c}-0.108 \\
(1.036)\end{array}$ \\
\hline $\begin{array}{l}\text { Weak IV 95\% AR } \\
\text { confidence set }\end{array}$ & $\begin{array}{c}{[-1.209} \\
1.252]\end{array}$ & $\begin{array}{c}{[-0.843} \\
2.181]\end{array}$ & $\begin{array}{c}{[-0.652} \\
2.797]\end{array}$ & $\begin{array}{c}{[-1.068} \\
1.100]\end{array}$ & $\begin{array}{c}{[-1.244} \\
1.035]\end{array}$ & $\begin{array}{c}{[-1.401} \\
1.131]\end{array}$ & $\begin{array}{c}{[-2.671} \\
3.274]\end{array}$ \\
\hline Mean outcome & 0.884 & 0.872 & 0.857 & 0.918 & 0.911 & 0.903 & 0.365 \\
\hline F-statistic $1^{\text {st }}$ stage & 7.16 & 7.16 & 7.16 & 7.16 & 7.16 & 7.16 & 7.16 \\
\hline Observations & 320,607 & 320,607 & 320,607 & 320,607 & 320,607 & 320,607 & 320,607 \\
\hline
\end{tabular}

Notes: Panels B and C split the sample up by household income (mean of the sum of maternal and paternal income in the two years prior to the first birth). In the first three columns the outcome variable is equal to one when the father and the child live at the same address. In columns 4 to 6 the outcome variable is equal to one if the father and child live in the same municipality. Column 7 is a dummy variable that is equal to one if the mother had a second child within 30 months. All specifications include area-level fixed effects, year of birth fixed effects, individual controls and postal code level controls. Robust standard errors are clustered at the area level and shown in in parentheses. ** $\mathrm{p}<0.01,{ }^{*} \mathrm{p}<0.05$. 
Table 5: Robustness results: first stage, antidepressant use and mental health care use

\begin{tabular}{|c|c|c|c|c|c|c|}
\hline & \multicolumn{3}{|c|}{ Antidepressant use } & \multicolumn{3}{|c|}{ Specialized Mental care } \\
\hline & $\begin{array}{c}\text { Mo } 1 \text { to } 10 \\
(1) \\
\end{array}$ & $\begin{array}{c}\text { Mo } 11 \text { to } \\
20 \\
(2)\end{array}$ & $\begin{array}{c}\text { Mo } 21 \text { to } \\
30 \\
(3) \\
\end{array}$ & $\begin{array}{c}\text { Mo } 1 \text { to } 10 \\
\text { (4) }\end{array}$ & $\begin{array}{c}\text { Mo } 11 \text { to } \\
20 \\
(5) \\
\end{array}$ & $\begin{array}{c}\text { Mo } 21 \text { to } \\
30 \\
(6) \\
\end{array}$ \\
\hline \multicolumn{7}{|c|}{ Panel A1: OLS - First births \& postal codes with fewer than 4 GP practices } \\
\hline AD 1-10 mo after birth & & $\begin{array}{l}0.577^{* *} \\
(0.006)\end{array}$ & $\begin{array}{c}0.388^{* *} \\
(0.006)\end{array}$ & $\begin{array}{c}0.390 * * \\
(0.009)\end{array}$ & $\begin{array}{l}0.359 * * \\
(0.010)\end{array}$ & $\begin{array}{l}0.274 * * \\
(0.010)\end{array}$ \\
\hline \multicolumn{7}{|c|}{ Panel A2: 2SLS - First births \& postal codes with fewer than 4 GP practices } \\
\hline New patients 45-65 & $\begin{array}{c}0.265^{* *} \\
(0.059)\end{array}$ & & & & & \\
\hline AD 1-10 mo after birth & & $\begin{array}{l}0.694^{* *} \\
(0.192)\end{array}$ & $\begin{array}{l}0.712^{* *} \\
(0.216)\end{array}$ & $\begin{array}{c}0.153 \\
(0.311)\end{array}$ & $\begin{array}{c}0.002 \\
(0.335)\end{array}$ & $\begin{array}{c}0.378 \\
(0.363)\end{array}$ \\
\hline $\begin{array}{l}\text { Weak IV 95\% AR } \\
\text { confidence set }\end{array}$ & & $\begin{array}{l}{[0.296 ;} \\
1.093]\end{array}$ & $\begin{array}{l}{[0.306 ;} \\
1.247]\end{array}$ & $\begin{array}{c}{[-0.554} \\
0.737]\end{array}$ & $\begin{array}{c}{[-0.893 ;} \\
0.632]\end{array}$ & $\begin{array}{c}{[-0.448} \\
1.203]\end{array}$ \\
\hline Mean outcome & 0.025 & 0.028 & 0.030 & 0.042 & 0.042 & 0.042 \\
\hline F-statistic 1st stage & 20.29 & 20.29 & 20.29 & 20.21 & 14.35 & 12.61 \\
\hline Observations & 275,160 & 275,160 & 275,160 & 163,296 & 137,671 & 111,907 \\
\hline \multicolumn{7}{|c|}{ Panel B1: OLS - First and second births } \\
\hline AD 1-10 mo after birth & & $\begin{array}{c}0.576^{* *} \\
(0.004) \\
\end{array}$ & $\begin{array}{l}0.404^{* *} \\
(0.004) \\
\end{array}$ & $\begin{array}{l}0.377^{* *} \\
(0.006) \\
\end{array}$ & $\begin{array}{l}0.339 * * \\
(0.007) \\
\end{array}$ & $\begin{array}{l}0.249 * * \\
(0.006)\end{array}$ \\
\hline \multicolumn{7}{|c|}{ Panel B2: 2SLS - First and second births } \\
\hline New patients $45-65$ & $\begin{array}{c}0.165 * * \\
(0.036)\end{array}$ & & & & & \\
\hline AD 1-10 mo after birth & & $\begin{array}{l}0.577^{* *} \\
(0.188)\end{array}$ & $\begin{array}{c}0.686 * * \\
(0.239)\end{array}$ & $\begin{array}{l}-0.309 \\
(0.301)\end{array}$ & $\begin{array}{c}0.237 \\
(0.265)\end{array}$ & $\begin{array}{c}0.333 \\
(0.291)\end{array}$ \\
\hline $\begin{array}{l}\text { Weak IV 95\% AR } \\
\text { confidence set }\end{array}$ & & $\begin{array}{l}{[0.187 ;} \\
0.967]\end{array}$ & $\begin{array}{l}{[0.236} \\
1.230]\end{array}$ & $\begin{array}{c}{[-1.053} \\
0.198]\end{array}$ & $\begin{array}{c}{[-0.313 ;} \\
0.735]\end{array}$ & $\begin{array}{c}{[-0.271 ;} \\
0.938]\end{array}$ \\
\hline Mean outcome & 0.025 & 0.029 & 0.033 & 0.041 & 0.041 & 0.041 \\
\hline F-statistic $1^{\text {st }}$ stage & 20.95 & 20.95 & 20.95 & 24.54 & 24.49 & 20.21 \\
\hline Observations & 768,740 & 768,740 & 768,740 & 457,171 & 385,010 & 312,657 \\
\hline $\begin{array}{l}\text { Notes: Panel A focuses on } \\
\text { which are spread out of } 42 \\
\text { antidepressant use dummies } \\
\text { least one script for antidepre } \\
\text { such care in the } 1 \text { to } 10,\end{array}$ & $\begin{array}{l}\text { first births in } t \\
4 \text { areas. The sa } \\
\text { for month } 1 \text { to } \\
\text { ssants in these }\end{array}$ & $\begin{array}{l}1,548 \text { post } \\
\text { ple in Pane } \\
0,11 \text { to } 20 \text {, }\end{array}$ & $\begin{array}{l}\text { odes that h } \\
\text { includes bo } \\
21 \text { to } 30 \text { ar } \\
\text { zed mental }\end{array}$ & $\begin{array}{l}\text { e fewer than } \\
\text { first and sec } \\
\text { equal to one i }\end{array}$ & $\begin{array}{l}\text { GP practice } \\
\text { dd births (N } \\
\text { he woman }\end{array}$ & $\begin{array}{l}(\mathrm{N}=275,160) \\
68,740) . \text { The } \\
\text { dispensed a } \\
\text { for receipt o } \\
\text { de area-leve }\end{array}$ \\
\hline
\end{tabular}




\section{References}

Alalouf, M., Miller, S., \& Wherry, L. R. (2019). What Difference Does a Diagnosis Make? Evidence From Marginal Patients. NBER Working Paper No. 26363.

Andrews, I., Stock, J. H., \& Sun, L. (2019). Weak instruments in instrumental variables regression: Theory and practice. Annual Review of Economics, 11, 727-753.

Bet, P., Hugtenburg, J., Penninx, B., \& Hoogendijk, W. (2013). Side effects of antidepressants during long-term use in a naturalistic setting. European Neuropsychopharmacology, 23(11), 1443-1451.

Bodnar-Deren, S., Klipstein, K., F.M., S., \& Howell, E. (2016). Suicidal Ideation During the Postpartum Period. Journal of Women's Health, 25(12), 1219-1224.

Bos, M., Hertzberg, A., \& Liberman, A. (2021). Are we Overdiagnosing Mental Illnesses? Evidence from Randomly Assigned Doctors. Working Paper, Febuary 2021.

Brody, D. J., \& Gu, Q. (2020). Antidepressant Use Among Adults: United States, 2015-2018. NCHS Data Brief, No. 377.

Burke, L. (2003). The Impact of Maternal Depression on Familial Relationships. International Review of Psychiatry, 15(3), 243-255.

Centers for Disease Control and Prevention. (Last updated 1 April 2016). Depression Evaluation Measures. Retrieved September 28, 2021, from https://www.cdc.gov/workplacehealthpromotion/health-strategies/depression/evaluationmeasures/index.html

Chorniy, A., \& Kitashima, L. (2016). Sex, Drugs, and ADHD: The Effects of ADHD Pharmacological Treatment on Teens' Risky Behaviors. Labour Economics, 43, 87-105. Cooper, P., Murray, L., Wilson, A., \& Romaniuk, H. (2003). Controlled Trial of the Short- and Long-Term Effect of Psychologial Treatment of Postpartum Depression: Impact on Maternal Mood. British Journal of Psychiatry, 182(5), 412-419.

Corman, H., Curtis, M. A., Noonan, K., \& Reichman, N. E. (2018). Maternal Depression as a Risk Factor for Children's Inadequate Housing Conditions. Social Science Medicine, 149, 76-83.

Cuddy, E., \& Currie, J. (2020). Rules Vs. Discretion: Treatment of Mental Illness in U.S. Adolescents. NBER Working Paper No. 27890. 
Currie, J., \& MacLeod, B. (2017). Diagnosing Expertise: Human Capital, Decision Making and Performance Among Physicians. Journal of Labor Economics, 35(1), 1-43.

Currie, J., \& MacLeod, B. (2020). Understanding Doctor Decision Making: The Case of Depression Treatment. Econometrica, 88(3), 847-878.

Curtis, M., Corman, H., Noonan, K., \& Reichmann, N. (2014). Maternal Depression as a Risk Factor for Family Homelessness. American Journal of Public Health, 104(9), 1664-1670.

Cutler, D., Skinner, J., Stern, A., \& Wennberg, D. (2019). Physician Beliefs and Patient Preferences: A New Look at Regional Variation in Health Care Spending. American Economic Journal: Economic Policy, 11(1), 192-221.

Dagher, R., Hofferth, S., \& Lee, Y. (2014). Maternal Depression, Pregnancy Intention, and Return to Paid Work After Childbirth. Women's Health Issues, 24(3), 297-303.

Dalsgaard, S., Skyt Nielsen, H., \& Simonsen, M. (2014). Consequences of Medication use for Children's Outcomes. Journal of Health Economics, 37, 137-151.

Davies, J., \& Read, J. (2019). A systematic review into the incidence, severity and duration of antidepressant withdrawal effects: Are guidelines evidence-based? Addictive Behaviors, 97, 111-121.

Finkelstein, A., Gentzkow, M., \& Williams, H. (2015). Sources of Geographic Variation in Health Care: Evidence From Patient Migration. The Quarterly Journal of Economics, 131(4), 1681-1726.

Fisher, E., Wennberg, D., Stukel, T., Gottlieb, D., Lucal, F., \& Pinder, E. (2003). The Implications of Regional Variations in Medicare Spending. Part 2: Health Outcomes and Satisfaction with Care. Annals of Internal Medicine, 138(4), 288-298.

Fisher, E., Wennberg, D., Stukel, T., Gottlieb, D., Lucas, F., \& Pinder, E. (2003). The Implications of Regional Variations in Medicare Spending. Annals of Internal Medicine, 138(4), 273-298.

Garg, A., Toy, S., Tripodis, Y., Cook, J., \& Cordella, N. (2015). Influence of Maternal Depression on Household Food Insecurity for Low-Income Families. Academic Pediatrics, 15(3), 305-310.

Lugtenberg, M., De Vries, P., Evertse, A., Zegers-van Schaick, J., Westert, G., \& Burgers, J. (2009). Welke Barrieres Ervaren Huisartsen bij de Toepassing van Aanbevelingen uit de NHG-Standaarden. Huisarts Wet, 53(1), 13-19. 
Maslej, M., Bolker, B., Russell, M., Eaton, K., Durisko, Z., Hollon, S., . . Mulsant, B. A. (2017). The Mortality and Myocardial Effects of Antidepressants Are Moderated by Preexisting Cardiovascular Disease: A Meta-Analysis. Psychotherapy and Psychosomatics, 86(5), 268-282.

Miller, L. J. (2002). Postpartum Depression. Journal of the American Medical Association, 287(6), 762-765.

MIND. (2019). Wat helpt bij depressie en somberheidsklachten? Inventarisatie van preventieve interventies onder mensen met somberheidsklachten en depressie en hun naasten en onder huisartsen en praktijkondersteunders GGZ. Landelijk Platform Geestelijke Gezondheid.

Ministerie voor Volksgezondheid, Welzijn en Sport. (2005, June 3). Beleidsregels ex artikel 4 Wet toelating zorginstellingen. Retrieved from https://opendata.rijksoverheid.nl/binaries/rijksoverheid/documenten/kamerstukken/2005/ 06/06/beleidsregels-wtzi/beleidsregels.pdf

Molenaar, N. M. (2018). Guidelines on Treatment of Perinatal Depression with Antidepressants: An International Review. Australian \& New Zealand Journal of Psychiatry, 52(4), 320327.

Molyneaux, E., Howard, L., McGeown, H., Karia, A., \& Trevillion, K. (2014). Antidepressant Treatment for Postnatal Depression. Cochrane Database of Systematic Reviews, 9.

Moore Simas, T., Huang, M., Patton, C., Reinhart, M., Chawla, A., Clemson, C., \& Eldar-Lissai, A. (2019). The Humanistic Burden of Postpartum Depression: A Systematic Literature Review. Current Medical Research and Opinion, 35(3), 383-393.

Moses-Kolko, E., \& Hipwell, A. (2016). First-onset Postpartum Depression Psychiatric Disorders Portend High 1-Year Unnatural-Cause Mortality Risk. American Journal of Psychiatry, 173(6), 559-561.

Netsi, E., Pearson, R. M., \& Murray, L. (2018). Association of Persistent and Severe Postnatal Depression With Child Outcomes. JAMA Psychiatry, 75(3), 247-253.

NHG. (2019, May). NHG-Standaard Depressie. M44, Versie 3.1.

Noonan, K., Corman, H., \& Reichman, N. E. (2016). Effects of Maternal Depression on Family Food Insecurity. Economics and Human Biology, 22, 201-215. 
NVOG. (2012). SSRI-Gebruik in de Zwangerschap en Tijdens de Lactatie. Nederlandse Vereniging voor Obstetrie and Gynaecologie.

O'Connor, E., Rossom, R., Henninger, M., Groom, H., \& Burda, B. (2016). Primary Care Screening For and Treatment of Depression in Pregnant and Postpartum Women: Evidence Report and Systematic Review for the US Preventative Services Task Force. Journal of the American Medical Association, 315(4), 388-406.

Office on Women's Health. (2019). Postpartum Depression. (U. D. Services, Producer)

Retrieved June 28, 2021, from https://www.womenshealth.gov/mental-health/mentalhealth-conditions/postpartum-depression

Persson, P., Qiu, X., \& Rossin-Slater, M. (2021). Family Spillover Effects of Marginal Diagnoses: The Case of ADHD. NBER Working Paper No. 28334.

Pratt, L., \& Brody, D. (2008). Depression in the United States household population, 2005-2006. National Center for Health Statistics: NCHS Data Brief No. 7.

SFK. (2005, June 10). Gebruik Antidepressiva Stijgt Sterk. Jaargang Pharmaceutisch Weekblad, 23, 767.

SFK. (2020, September 17). Specialist Initiator Van 29\% Antidepressiva. Pharmaceutisch Weekblad, 155(38).

Slomian, J., Honvo, G., Emonts, P., Reginster, J., \& Bruyere, O. (2019). Consequences of Maternal Postpartum Depression: A Systematic Review of Maternal and Infant Outcomes. Women's Health, 15.

Spies, T., Mokkink, H., De Vries Robbé, P., \& Grol, R. (2004). Huisarts Kiest Vaak Voor Antidepressiva Onafhankelijk van de Ernst van de Depressie. Huisarts Wet, 47(8), 364367.

Sun, L. (2018). Implementing valid two-step identification-robust confidence sets for linear instrumental-varaibles models. The Stata Journal, 18(4), 803-825.

Van Dijk, C. E., Van den Berg, B., Verheij, R. A., Spreeuwenberg, P., Groenewegen, P., \& De Bakker, D. H. (2013). Moral Hazard and Supplier-Induced Demand: Emprical Evidence in General Practice. Health Economics, 22, 340-352.

Vliegen, N., Casalin, S., \& Luyten, P. (2014). The Course of Postpartum Depression: A Review of Longitudinal Studies. Harvard Review of Psychiatry, 22(1), 1-22. 
Williams, D. T., \& Cheadle, J. E. (2015). Economic Hardship, Parents' Depression, and Relationship Distress among Couples With Young Children. Scoeity and Mental Health, 6(2), 73-89. 


\section{Appendix A: Additional Tables and Figures}

Figure A1: Antidepressant usage by parity

(a) Raw data

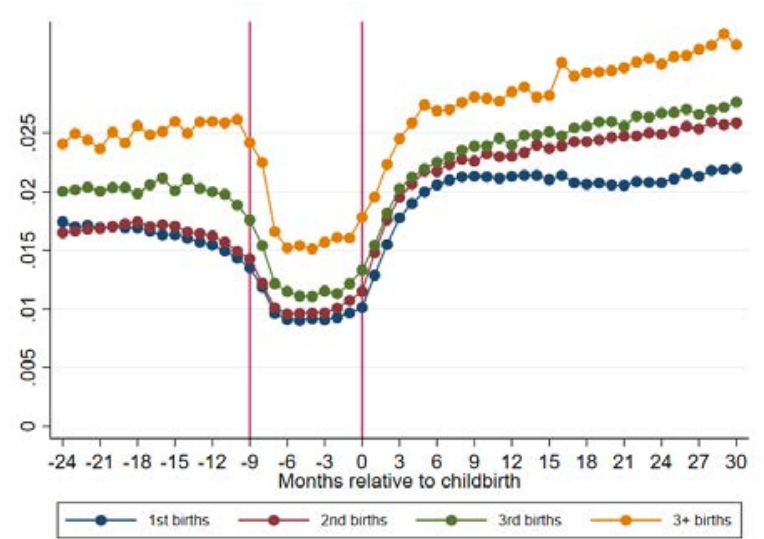

(b) Residualized data

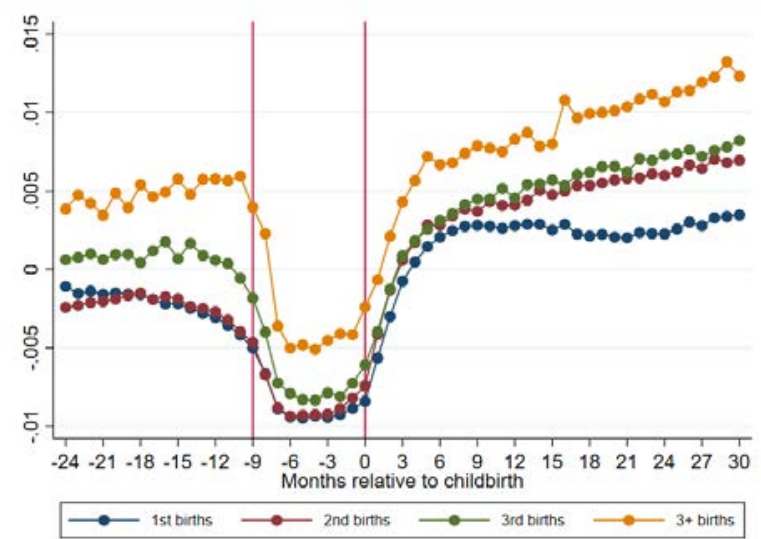

Notes: Panel (a) reports proportion of individuals dispensing a script for antidepressants at a pharmacy in each month relative to childbirth by birth order $(\mathrm{N}=952,541)$. It splits the sample into four groups depending on birth order. Panel (b) plots the residuals after controlling for maternal age at birth. 
Table A1: Summary statistics for outcome and control variables, by prescribing intensity.

\begin{tabular}{|c|c|c|c|c|}
\hline & $\begin{array}{l}\text { All } \\
(1) \\
\end{array}$ & $\begin{array}{l}\text { Bottom } \\
\text { Tercile } \\
(2)\end{array}$ & $\begin{array}{l}\text { Middle } \\
\text { Tercile } \\
\text { (3) }\end{array}$ & $\begin{array}{c}\text { Top } \\
\text { Tercile } \\
(4) \\
\end{array}$ \\
\hline Number of observations & 427,475 & 137,855 & 142,353 & 147,267 \\
\hline $\begin{array}{l}\text { Antidepressants 1-10 mo. } \\
\text { Outcome variables }\end{array}$ & 0.025 & 0.021 & 0.024 & 0.028 \\
\hline Antidepressants 11 to 20 mo. & 0.028 & 0.024 & 0.028 & 0.032 \\
\hline Antidepressants 21 to $30 \mathrm{mo}$. & 0.030 & 0.026 & 0.029 & 0.035 \\
\hline Specialized treatment 1 to $10 \mathrm{mo}$. & 0.044 & 0.039 & 0.045 & 0.050 \\
\hline Specialized treatment 11 to $20 \mathrm{mo}$. & 0.044 & 0.038 & 0.043 & 0.050 \\
\hline Specialized treatment 21 to $30 \mathrm{mo}$. & 0.043 & 0.038 & 0.042 & 0.049 \\
\hline Second birth $<24$ months & 0.226 & 0.236 & 0.225 & 0.218 \\
\hline Second birth $<30$ months & 0.393 & 0.413 & 0.391 & 0.377 \\
\hline Mother income >0 Y1 & 0.910 & 0.928 & 0.916 & 0.886 \\
\hline Mother income>0 Y2 & 0.905 & 0.923 & 0.911 & 0.883 \\
\hline Mother income $>0 \mathrm{Y} 3$ & 0.900 & 0.919 & 0.907 & 0.877 \\
\hline Mother income Y1, if positive & 30,590 & 31,200 & 31,147 & 29,438 \\
\hline Mother income Y2, if positive & 31,947 & 32,491 & 32,541 & 30,821 \\
\hline Mother income Y3, if positive & 33,332 & 33,792 & 33,980 & 32,231 \\
\hline Father income $>0$ Y1 & 0.976 & 0.982 & 0.977 & 0.970 \\
\hline Father income $>0$ Y2 & 0.974 & 0.980 & 0.976 & 0.967 \\
\hline Father income $>0 \mathrm{Y3}$ & 0.972 & 0.978 & 0.974 & 0.965 \\
\hline Father income $\mathrm{Y} 1$, if positive & 51,295 & 52,834 & 52,215 & 48,860 \\
\hline Father income Y2, if positive & 54,535 & 56,055 & 55,519 & 52,053 \\
\hline Father income Y3, if positive & 57,796 & 59,308 & 58,847 & 55,254 \\
\hline Father \& child same addr Y1 & 0.906 & 0.927 & 0.909 & 0.882 \\
\hline Father \& child same addr Y2 & 0.896 & 0.919 & 0.900 & 0.872 \\
\hline Father \& child same addr Y3 & 0.884 & 0.908 & 0.888 & 0.858 \\
\hline Father \& child same mun. Y1 & 0.934 & 0.947 & 0.936 & 0.919 \\
\hline Father \& child same mun. Y2 & 0.928 & 0.943 & 0.931 & 0.913 \\
\hline Father \& child same mun. Y3 & 0.922 & 0.936 & 0.924 & 0.905 \\
\hline \multicolumn{5}{|l|}{ Individual-level controls } \\
\hline Maternal age at birth & 29.44 & 29.66 & 29.60 & 29.09 \\
\hline Paternal age at birth & 32.23 & 32.46 & 32.36 & 31.89 \\
\hline Mother Dutch background & 0.867 & 0.908 & 0.877 & 0.820 \\
\hline Father Dutch background & 0.808 & 0.857 & 0.817 & 0.752 \\
\hline Multiple birth & 0.017 & 0.017 & 0.017 & 0.017 \\
\hline $\begin{array}{l}\text { Parents living together yr before } \\
\text { birth }\end{array}$ & 0.775 & 0.806 & 0.779 & 0.744 \\
\hline Mother income>0, bef. birth & 0.968 & 0.974 & 0.971 & 0.959 \\
\hline $\begin{array}{l}\text { Mother income, before birth, } \\
\text { if positive }\end{array}$ & 31,073 & 32,504 & 31,763 & 29,066 \\
\hline
\end{tabular}




\begin{tabular}{lcccc}
\hline Father income>0, bef. birth & 0.943 & 0.959 & 0.946 & 0.926 \\
Father income,before birth, & 40,493 & 42,901 & 41,452 & 37,312 \\
$\quad$ if positive & & & & \\
& & & & \\
Postal code level controls & 75.51 & 82.76 & 77.92 & 69.28 \\
Percent Dutch & 7.19 & 6.43 & 7.07 & 8.01 \\
Percent one parent households & 9.70 & 7.84 & 9.32 & 11.82 \\
Percent on benefits & 40.96 & 35.29 & 39.87 & 47.32 \\
Percent low income households & 2.49 & 2.92 & 2.42 & 2.13 \\
Mean urbanicity & $9,546.0$ & $8,674.6$ & 10,028 & $9,896.3$ \\
Mean population & 20,398 & 21,387 & 21,076 & 18,818 \\
Mean income women 15-45 & 34,343 & 36,902 & 35,259 & 31,062 \\
Mean income men 15-45 & 0.814 & 0.833 & 0.822 & 0.788 \\
Mean pos. income women 15-45 & 0.863 & 0.875 & 0.867 & 0.847 \\
Mean pos. income men 15-45 & & & \\
\hline
\end{tabular}

Notes: Column (1) shows summary statistics for the full sample, and in columns (2) to (4) we divide individuals up in terciles according to prescribing intensity to women aged 46 to 65 in their postal code in the year before the women gave birth. The sample size for each column is shown in the first row, but is lower for outcomes related to specialized mental health care usage because we only observe these outcomes from 2011 to 2016, and for outcomes related to father's labor market outcomes (because we focus on the outcomes of fathers that we observe in all years surrounding childbirth). 
Table A2: Labor market outcomes for fathers after birth

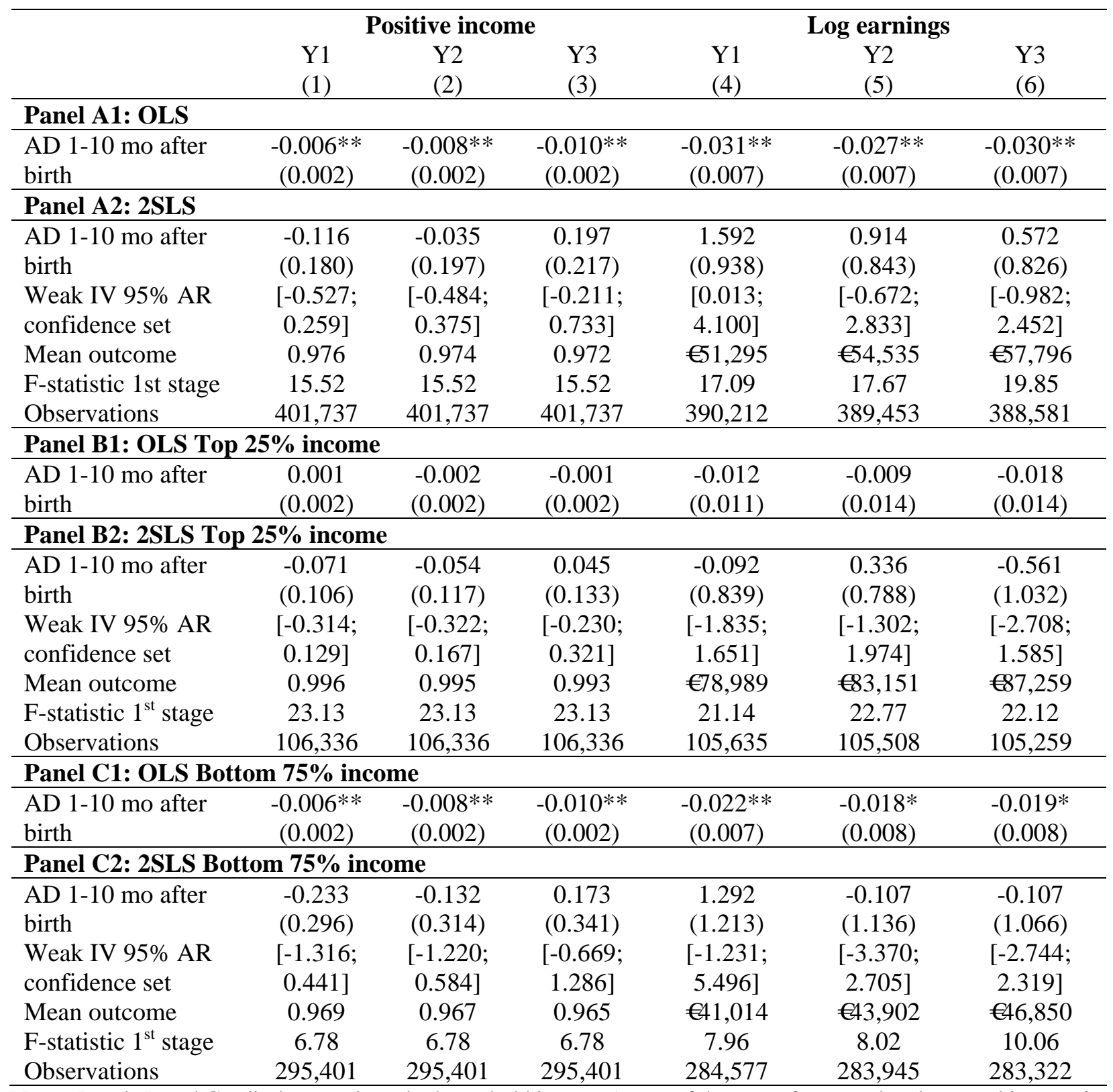

Notes: Panels B and C split the sample up by household income (mean of the sum of maternal and paternal income in the two years prior to first birth). Positive income is a dummy variable and indicates that an individual had income greater than zero in the full calendar years after the birth year (Y1-Y3). Log earnings conditional on employment (after an inflation correction) is also reported for the three years after the birth year (Y1-Y3). The number of observations is lower because we restrict the sample to births for which we observe the father, and income of the father in the 2 calendar years prior to the birth year, the year of birth, and the 3 calendar years after childbirth. All specifications include area-level fixed effects, year of birth fixed effects, individual controls and postal code level controls. Robust standard errors are clustered at the area level and are shown in parentheses. ${ }^{* *} \mathrm{p}<0.01,{ }^{*} \mathrm{p}<0.05$. 
Table A3: Family formation Part II

\begin{tabular}{|c|c|c|c|c|c|c|c|}
\hline & \multicolumn{3}{|c|}{ Mother lives at same address } & \multicolumn{3}{|c|}{ Mother lives in same area } & \multirow{2}{*}{$\begin{array}{c}2^{\text {nd }} \text { birth } \\
<24 \text { mo } \\
(7)\end{array}$} \\
\hline & $\begin{array}{l}\mathrm{Y} 1 \\
(1)\end{array}$ & $\begin{array}{l}\mathrm{Y} 2 \\
\text { (2) }\end{array}$ & $\begin{array}{l}\text { Y3 } \\
\text { (3) }\end{array}$ & $\begin{array}{l}\mathrm{Y} 1 \\
(4)\end{array}$ & $\begin{array}{l}\mathrm{Y} 2 \\
\text { (5) }\end{array}$ & $\begin{array}{l}\mathrm{Y} 3 \\
(6)\end{array}$ & \\
\hline \multicolumn{8}{|l|}{ Panel A1: OLS } \\
\hline $\begin{array}{l}\text { AD 1-10 mo after } \\
\text { birth }\end{array}$ & $\begin{array}{c}-0.004^{* *} \\
(0.001)\end{array}$ & $\begin{array}{c}-0.007 * * \\
(0.001)\end{array}$ & $\begin{array}{c}-0.008^{* *} \\
(0.001)\end{array}$ & $\begin{array}{c}-0.004^{* *} \\
(0.001)\end{array}$ & $\begin{array}{c}-0.005^{* *} \\
(0.001) \\
\end{array}$ & $\begin{array}{c}-0.005^{* *} \\
(0.001)\end{array}$ & $\begin{array}{c}-0.091^{* *} \\
(0.004) \\
\end{array}$ \\
\hline \multicolumn{8}{|l|}{ Panel A2: 2SLS } \\
\hline $\begin{array}{l}\text { AD 1-10 mo after } \\
\text { birth } \\
\text { Weak IV 95\% AR } \\
\text { confidence set } \\
\text { Mean outcome } \\
\text { F-statistic 1st stage } \\
\text { Observations }\end{array}$ & $\begin{array}{c}0.055 \\
(0.120) \\
{[-0.171 ;} \\
0.352] \\
0.993 \\
15.23 \\
427,475\end{array}$ & $\begin{array}{c}0.080 \\
(0.129) \\
{[-0.163 ;} \\
0.399] \\
0.992 \\
15.23 \\
427,475\end{array}$ & $\begin{array}{c}0.052 \\
(0.141) \\
{[-0.242 ;} \\
0.374] \\
0.990 \\
15.23 \\
427,475\end{array}$ & $\begin{array}{c}0.036 \\
(0.112) \\
{[-0.197} \\
0.291] \\
0.994 \\
15.23 \\
427,475\end{array}$ & $\begin{array}{c}0.081 \\
(0.120) \\
{[-0.145} \\
0.379] \\
0.994 \\
15.23 \\
427,475\end{array}$ & $\begin{array}{c}0.086 \\
(0.125) \\
{[-0.148} \\
0.395] \\
0.993 \\
15.23 \\
427,475\end{array}$ & $\begin{array}{c}-0.394 \\
(0.620) \\
{[-1.806} \\
0.895] \\
0.226 \\
15.23 \\
427,475\end{array}$ \\
\hline \multicolumn{8}{|c|}{ Panel B1: OLS Top 25\% income } \\
\hline $\begin{array}{l}\text { AD 1-10 mo after } \\
\text { birth }\end{array}$ & $\begin{array}{c}-0.001 \\
(0.002)\end{array}$ & $\begin{array}{l}-0.000 \\
(0.002) \\
\end{array}$ & $\begin{array}{l}-0.000 \\
(0.002)\end{array}$ & $\begin{array}{c}-0.001 \\
(0.002)\end{array}$ & $\begin{array}{l}-0.001 \\
(0.002)\end{array}$ & $\begin{array}{l}-0.001 \\
(0.002)\end{array}$ & $\begin{array}{c}-0.145^{* *} \\
(0.010)\end{array}$ \\
\hline \multicolumn{8}{|c|}{ Panel B2: 2SLS Top 25\% income } \\
\hline $\begin{array}{l}\text { AD 1-10 mo after } \\
\text { birth } \\
\text { Weak IV 95\% AR } \\
\text { confidence set } \\
\text { Mean outcome } \\
\text { F-statistic } 1^{\text {st }} \text { stage } \\
\text { Observations }\end{array}$ & $\begin{array}{c}0.080 \\
(0.134) \\
{[-0.172 ;} \\
0.385] \\
0.995 \\
21.88 \\
106,868\end{array}$ & $\begin{array}{c}-0.023 \\
(0.134) \\
{[-0.301 ;} \\
0.256] \\
0.995 \\
21.88 \\
106,868\end{array}$ & $\begin{array}{c}-0.031 \\
(0.138) \\
{[-0.317 ;} \\
0.256] \\
0.994 \\
21.88 \\
106,868\end{array}$ & $\begin{array}{c}0.034 \\
(0.116) \\
{[-0.185 ;} \\
0.276] \\
0.996 \\
21.88 \\
106,868\end{array}$ & $\begin{array}{c}0.009 \\
(0.119) \\
{[-0.214 ;} \\
0.279] \\
0.996 \\
21.88 \\
106,868\end{array}$ & $\begin{array}{c}-0.068 \\
(0.125) \\
{[-0.328} \\
0.191] \\
0.995 \\
21.88 \\
106,868\end{array}$ & $\begin{array}{c}-0.684 \\
(0.804) \\
{[-2.514 ;} \\
0.828] \\
0.279 \\
21.88 \\
106,868\end{array}$ \\
\hline \multicolumn{8}{|c|}{ Panel C1: OLS Bottom 75\% income } \\
\hline $\begin{array}{l}\text { AD 1-10 mo after } \\
\text { birth }\end{array}$ & $\begin{array}{c}-0.004^{* *} \\
(0.001)\end{array}$ & $\begin{array}{c}-0.007 * * \\
(0.001)\end{array}$ & $\begin{array}{c}-0.009 * * \\
(0.002)\end{array}$ & $\begin{array}{c}-0.004^{* *} \\
(0.001)\end{array}$ & $\begin{array}{c}-0.005^{* *} \\
(0.001)\end{array}$ & $\begin{array}{c}-0.006 * * \\
(0.001)\end{array}$ & $\begin{array}{c}-0.081^{* *} \\
(0.004)\end{array}$ \\
\hline \multicolumn{8}{|c|}{ Panel C2: 2SLS Bottom 75\% income } \\
\hline $\begin{array}{l}\text { AD 1-10 mo after } \\
\text { birth } \\
\text { Weak IV 95\% AR } \\
\text { confidence set } \\
\text { Mean outcome } \\
\text { F-statistic } 1^{\text {st }} \text { stage } \\
\text { Observations }\end{array}$ & $\begin{array}{c}0.030 \\
(0.172) \\
{[-0.396 ;} \\
0.558] \\
0.993 \\
7.16 \\
320,607\end{array}$ & $\begin{array}{c}0.119 \\
(0.193) \\
{[-0.282} \\
0.864] \\
0.991 \\
7.16 \\
320,607\end{array}$ & $\begin{array}{c}0.084 \\
(0.207) \\
{[-0.386 ;} \\
0.758] \\
0.989 \\
7.16 \\
320,607\end{array}$ & $\begin{array}{c}0.027 \\
(0.158) \\
{[-0.364 ;} \\
0.513] \\
0.994 \\
7.16 \\
320,607\end{array}$ & $\begin{array}{c}0.108 \\
(0.174) \\
{[-0.254 ;} \\
0.745] \\
0.993 \\
7.16 \\
320,607\end{array}$ & $\begin{array}{c}0.162 \\
(0.185) \\
{[-0.186 ;} \\
0.913] \\
0.992 \\
7.16 \\
320,607\end{array}$ & $\begin{array}{c}-0.430 \\
(0.853) \\
{[-3.217} \\
1.681] \\
0.209 \\
7.16 \\
320,607\end{array}$ \\
\hline
\end{tabular}

Notes: Panels B and C split the sample up by household income (mean of the sum of maternal and paternal income in the two years prior to first birth). In the first three columns the outcome variable is equal to one when the mother and the child live at the same address, in column 4 to 6 the outcome variable is equal to one if the mother and child live in the same area (i.e. municipality). Column 7 is a dummy variable that is equal to one if the mother had a second child within 24 months. All specifications include area-level fixed effects, year of birth fixed effects, individual controls and postal code level controls. Robust standard errors are clustered at the area level and are shown in parentheses. ** $\mathrm{p}<0.01,{ }^{*} \mathrm{p}<0.05$. 
Table A4: Heterogeneity: first stage, antidepressant use and mental health care use

\begin{tabular}{|c|c|c|c|c|c|c|}
\hline & \multicolumn{3}{|c|}{ Antidepressant use } & \multicolumn{3}{|c|}{ Specialized Mental care } \\
\hline & $\begin{array}{l}\text { Mo } 1 \text { to } 10 \\
\text { (1) }\end{array}$ & $\begin{array}{c}\text { Mo } 11 \text { to } \\
20 \\
(2)\end{array}$ & $\begin{array}{c}\text { Mo } 21 \text { to } \\
30 \\
\text { (3) }\end{array}$ & $\begin{array}{l}\text { Mo } 1 \text { to } 10 \\
\text { (4) }\end{array}$ & $\begin{array}{c}\text { Mo } 11 \text { to } \\
20 \\
\text { (5) }\end{array}$ & $\begin{array}{c}\text { Mo } 21 \text { to } \\
30 \\
(6)\end{array}$ \\
\hline \multicolumn{7}{|c|}{ Panel A1: OLS - Mothers with Dutch migration background } \\
\hline AD 1-10 mo after birth & & $\begin{array}{l}0.575^{* *} \\
(0.006)\end{array}$ & $\begin{array}{c}0.395^{* *} \\
(0.005)\end{array}$ & $\begin{array}{l}0.385^{* *} \\
(0.008)\end{array}$ & $\begin{array}{l}0.343^{* *} \\
(0.009)\end{array}$ & $\begin{array}{l}0.261^{* *} \\
(0.009)\end{array}$ \\
\hline \multicolumn{7}{|c|}{ Panel A2: 2SLS - Mothers with Dutch migration background } \\
\hline New patients $45-65$ & $\begin{array}{c}0.189 * * \\
(0.054)\end{array}$ & & & & & \\
\hline AD 1-10 mo after birth & & $\begin{array}{c}0.709^{* *} \\
(0.228)\end{array}$ & $\begin{array}{l}0.664^{*} \\
(0.266)\end{array}$ & $\begin{array}{c}0.069 \\
(0.370)\end{array}$ & $\begin{array}{c}0.132 \\
(0.402)\end{array}$ & $\begin{array}{c}0.615 \\
(0.513)\end{array}$ \\
\hline $\begin{array}{l}\text { Weak IV 95\% AR } \\
\text { confidence set }\end{array}$ & & $\begin{array}{l}{[0.190} \\
1.228]\end{array}$ & $\begin{array}{l}{[0.112 ;} \\
1.322]\end{array}$ & $\begin{array}{c}{[-0.920} \\
0.839]\end{array}$ & $\begin{array}{c}{[-0.943 ;} \\
0.967]\end{array}$ & $\begin{array}{c}{[-0.452} \\
2.494]\end{array}$ \\
\hline Mean outcome & 0.023 & 0.026 & 0.028 & 0.041 & 0.040 & 0.039 \\
\hline F-statistic 1st stage & 12.36 & 12.36 & 12.36 & 11.72 & 9.45 & 7.24 \\
\hline Observations & 370,679 & 370,679 & 370,679 & 219,282 & 185,350 & 150,679 \\
\hline \multicolumn{7}{|c|}{ Panel B1: OLS - Older mothers } \\
\hline AD 1-10 mo after birth & & $\begin{array}{l}0.608 * * \\
(0.007) \\
\end{array}$ & $\begin{array}{l}0.410^{* *} \\
(0.008)\end{array}$ & $\begin{array}{l}0.421^{* *} \\
(0.010) \\
\end{array}$ & $\begin{array}{l}0.361^{* *} \\
(0.011) \\
\end{array}$ & $\begin{array}{l}0.261 * * \\
(0.012) \\
\end{array}$ \\
\hline \multicolumn{7}{|c|}{ Panel B2: 2SLS - Older mothers } \\
\hline New patients $45-65$ & $\begin{array}{c}0.187 * * \\
(0.061)\end{array}$ & & & & & \\
\hline AD 1-10 mo after birth & & $\begin{array}{c}0.308 \\
(0.305)\end{array}$ & $\begin{array}{c}0.233 \\
(0.345)\end{array}$ & $\begin{array}{l}-0.096 \\
(0.398)\end{array}$ & $\begin{array}{l}-0.826 \\
(0.571)\end{array}$ & $\begin{array}{l}-0.244 \\
(0.510)\end{array}$ \\
\hline $\begin{array}{l}\text { Weak IV 95\% AR } \\
\text { confidence set }\end{array}$ & & $\begin{array}{c}{[-0.627} \\
0.881]\end{array}$ & $\begin{array}{c}{[-0.758} \\
0.951]\end{array}$ & $\begin{array}{c}{[-1.160} \\
0.652]\end{array}$ & $\begin{array}{l}{[-3.144} \\
-0.091]\end{array}$ & $\begin{array}{c}{[-2.013} \\
0.716]\end{array}$ \\
\hline Mean outcome & 0.020 & 0.023 & 0.024 & 0.040 & 0.038 & 0.036 \\
\hline F-statistic $1^{\text {st }}$ stage & 9.47 & 9.47 & 9.47 & 13.86 & 9.97 & 8.14 \\
\hline Observations & 210,959 & 210,959 & 210,959 & 125,670 & 105,665 & 85,602 \\
\hline \multicolumn{7}{|c|}{ Panel C1: OLS - Younger mothers } \\
\hline AD 1-10 mo after birth & & $\begin{array}{l}0.550 * * \\
(0.007) \\
\end{array}$ & $\begin{array}{l}0.376 * * \\
(0.007) \\
\end{array}$ & $\begin{array}{c}0.387 * * \\
(0.010) \\
\end{array}$ & $\begin{array}{l}0.365^{* *} \\
(0.011) \\
\end{array}$ & $\begin{array}{c}0.290 * * \\
(0.010)\end{array}$ \\
\hline \multicolumn{7}{|c|}{ Panel C2: 2SLS - Younger mothers } \\
\hline New patients 45-65 & $\begin{array}{c}0.202 * * \\
(0.071)\end{array}$ & & & & & \\
\hline AD 1-10 mo after birth & & $\begin{array}{c}0.865 * * \\
(0.317)\end{array}$ & $\begin{array}{l}1.056 * * \\
(0.403)\end{array}$ & $\begin{array}{c}0.258 \\
(0.549)\end{array}$ & $\begin{array}{c}0.820 \\
(0.595)\end{array}$ & $\begin{array}{c}0.625 \\
(0.606)\end{array}$ \\
\hline $\begin{array}{l}\text { Weak IV 95\% AR } \\
\text { confidence set }\end{array}$ & & $\begin{array}{c}{[0.206 ;} \\
1.902]\end{array}$ & $\begin{array}{c}{[0.458} \\
2.852]\end{array}$ & $\begin{array}{c}{[-1.426} \\
1.943]\end{array}$ & $\begin{array}{c}{[-0.298 ;} \\
4.412]\end{array}$ & $\begin{array}{c}{[-1.115 ;} \\
5.963]\end{array}$ \\
\hline Mean outcome & 0.030 & 0.033 & 0.036 & 0.049 & 0.050 & 0.050 \\
\hline F-statistic $1^{\text {st }}$ stage & 8.09 & 8.09 & 8.09 & 6.15 & 5.51 & 4.43 \\
\hline Observations & 216,516 & 216,516 & 216,516 & 128,819 & 108,952 & 88,647 \\
\hline
\end{tabular}

Notes: Panel A focuses on mothers with a Dutch migration background. Panel B and C split the sample by maternal age at birth (above and below median). The antidepressant use dummies for month 1 to 10,11 to 20, and 21 to 30 are equal to one if the woman was dispensed at least one script for antidepressants in these months. Specialized mental health care is a dummy variable for receipt of such care in the 1 to 10,11 to 20, or 21 to 30 months after giving birth. All specifications include area-level (municipality) fixed effects, individual controls and postal code level controls. Robust standard errors are clustered at the area level and shown in parentheses. ${ }^{* *} \mathrm{p}<0.01,{ }^{*} \mathrm{p}<0.05$ 